\title{
Economic analysis of the link between diet quality and health: Evidence from Kosovo
}

Kushtrim Braha, Faculty of Economics and Management, Slovak University of Agriculture, kbraha@gmail.com.

Andrej Cupák, Research Department, National Bank of Slovakia, andrej.cupak@nbs.sk.

Ján Pokrivčák, Faculty of Economics and Management, Slovak University of Agriculture, jan.pokrivcak@uniag.sk.

Artan Qineti, Faculty of Economics and Management, Slovak University of Agriculture, artan.qineti@uniag.sk.

Marian Rizov (corresponding author) Lincoln International Business School, University of Lincoln, Brayford Pool, Lincoln LN6 7TS, United Kingdom, mrizov@lincoln.ac.uk.

\section{Acknowledgments}

This research was supported by the Slovak Research and Development Agency under the contract No: APVV-15-0552 and No: APVV-16-0321. The authors also acknowledge financial support from the projects VEGA 1/0806/15, VEGA 1/0930/15, VEGA 1/0797/16, VEGA 1/0935/17, VEGA 1/0928/17. We thank the Kosovar Statistical Office for granting access to the Household Budget Survey data. We thank the editor and three anonymous referees for constructive comments. The authors are solely responsible for the content of the paper. The views expressed are purely those of the authors and may not in any circumstances be regarded as stating an official position of the National Bank of Slovakia or the Eurosystem. Authors' names are listed alphabetically to indicate equal contributions to the paper.

\begin{abstract}
We analyse the link between diet diversity, which is a proxy of diet quality and health outcomes measured by body-mass index (BMI) in a representative sample of Kosovar adults using household expenditure micro-data. Building on a household model of health production we devise a two-stage empirical strategy to estimate the antecedents of diet diversity and its effect on BMI. Economic factors and demographic characteristics play an important role in the choice of balanced diets. Results from the BMI analysis support the hypothesis that diet diversity is associated with optimal BMI. One standard deviation increase in diet diversity leads to $2.3 \%$ increase in BMI of the underweight individuals and to $1.5 \%$ reduction in BMI of the obese individuals. The findings have important implications for food security policies aiming at enhancing the public health in Kosovo.
\end{abstract}

Keywords: BMI, diet diversity, food security, diet quality, health, Kosovo

JEL codes: D11, D12, D13, I12, I15 


\section{Economic analysis of the link between diet quality and health: Evidence from Kosovo}

\section{$1 \quad$ Introduction}

Despite progress made in recent years towards poverty alleviation and inclusive growth a significant number of people suffer from food insecurity and undernourishment globally (FAO, 2015). In Kosovo - one of the poorest European transition countries - despite relatively high economic growth since the post-conflict reconstruction, the socio-economic environment can be characterised as a mix of poverty, food insecurity, and galloping unemployment. Kosovar households in urban areas spent more than 40 percent of their income on food whereas rural households depend heavily on their own food production (Sen and Kirkpatric, 2011; Duval and Wolff, 2013). Countries where food expenditures constitute significant share of households' incomes are the most vulnerable and food insecure (e.g., Clapp and Cohen, 2009; McMichael and Schneider, 2011). ${ }^{1}$

Food insecurity is closely associated with poor diets, suboptimal nutrition, and consequently worsening health status (Hatloy et al., 1998; Thomas and Frankenberg, 2002; Sirotin et al., 2012). Darmon and Drewnowski (2008) note that monotonous, energy-dense and nutrient-poor diets are cheap and more common for those with limited means; socio-economic conditions are therefore important predictors of diet quality. Diets of many households in transition countries are particularly monotonous, mainly based on cheap cereal products (Swinnen and Van Herck, 2011). Quality of diets in transition countries depends heavily on real incomes, prices, and household socio-economic characteristics as a large proportion of households have nutrition-poor diets (e.g., Moon et al., 2002; Herzfeld et al., 2014; Cupák et al., 2016). Poor diets lead to the extremes of either undernourishment or overweight and obesity and ultimately to poor health both in adult and infant populations (e.g., Kant et al., 1995; Kennedy, 2004; Azadbakht et al., 2006; Rosinger et al., 2013). ${ }^{2}$

\footnotetext{
${ }^{1}$ The food security concept was formulated in 1996 at the World Food Summit (WFS) in Rome where the Declaration on World Food Security was adopted. The concept comprises supply and demand factors and has four major aspects: availability (adequate food supplies), access (people's ability to access the available food supplies), utilisation (calorie and micronutrient intake and absorption), and stability (environmental, economic and political stability in access to food). Commonly, the access to food is reflected in the share of income spent on food while the utilisation of food is captured by the quality of diet for which access is a necessary condition (Carletto et al., 2013; FAO, 2015). Smith et al. (2000) offer a conceptual framework capturing the various dimensions of food security and their interactions.

2 The association between obesity and poor health-related quality of life (HRQL) has been explored from various angles. Kortt and Dollery (2011) investigated the correlation between HRQL and measures of obesity in a representative sample of the Australian general population and found a negative association. McDonough et al. (2013) provided further evidence for the association between increasing obesity and poorer HRQL in a mixed population of white European and South Asian ethnicities. Even though results on the link between obesity and health in some contexts are somewhat mixed the overall message is that obesity (fatness) and health are negatively associated (Nuttall, 2015).
} 
Comparing countries in Europe, overweight and obesity are more widespread in the low to middle-income Central and East European (CEE) transition countries relative to the high-income, developed European countries. The rising trend in overweight and obesity in many of the CEE countries have also been documented in a descriptive study by Knai et al. (2007) who show that up to $6 \%$ of the total healthcare costs can be attributed directly to obesity and consequent illnesses which may have important implications for the population's economic productivity.

Overweight and obesity, measured by the Body-Mass Index (BMI $)^{3}$, and its determinants have been studied with detailed micro-data in a number of developed European countries (e.g., GutiérrezFisac, 1999 for Spain; Ali and Lindström, 2005 for Sweden; Kleiser et al., 2009 for Germany). However, studies on the transition CEE countries are limited which presents a significant gap in the literature. ${ }^{4}$ Furthermore, considering that economic development of transition countries has not reached the West European levels yet, there are important challenges remaining for the food security status and health of the population which makes our study very relevant.

Kosovo offers an important case study of the link between food security, diet, obesity and health from both scientific and policy intervention viewpoints. Kosovo is one of the poorest transition CEE countries, with per capita annual GDP at about 3,000 Euro; 29.7\% of its population lives below the poverty line and $10.2 \%$ of the population lives in extreme poverty (World Bank/KAS, 2011). Although a significant annual GDP growth of $4.5 \%$ is marked since the early 2000s, economic growth has had limited impact on poverty reduction and public health improvement (UNDP 2014; World Bank, 2015). Thus, the food security situation in Kosovo and its impact on health remains an important development issue. So far the focus in Kosovo has mostly been on supply side policies promoting the contribution of agriculture to food availability as a part of the food security agenda (Osmani et al., 2013; MAFRD, 2014; Braha et al., 2015).

The focus of this paper is on the demand side factors affecting food utilisation such as diet quality, proxied by different diet diversity measures. ${ }^{5}$ Furthermore, we analyse the link between diet

\footnotetext{
${ }^{3}$ The Body-Mass Index (BMI), originally known as Quetelet Index, is equal to body weight (kilograms) divided by height (meters) squared. By squaring the height, it reduces the contribution of leg length in the equation and tends to normalise the body mass distribution at each level of height; that is, it reduces the effect of a variance in height in the relationship of weight to height. Even though BMI has shortcomings as it rather poorly represents a person's percentage of body fat the index has been adopted by the World Health Organization (WHO) since the 1990s as the main criteria for defining obesity (Nuttall, 2015).

${ }^{4}$ Some exceptions are studies based on Russian individual data evaluating food demand patterns and rise of obesity in Russia (e.g., Huffman and Rizov, 2007; 2010; Herzfeld et al., 2014).There are also a few relevant studies on the link between food expenditure, consumption, BMI and health in developing country context. Campbell et al. (2010) and Thorne-Lyman et al. (2010) provide insides from Bangladesh, Sirotin et al. (2012) - from Rwanda, Rosinger et al. (2013) - from Bolivia, and Humphries et al. (2017) - from four other developing countries.

${ }^{5}$ Diet diversity is an important characteristic of the quality of diet. However, other factors such as the composition of macro and micro nutrients in the diet and the quantity and quality of the calorie intake all have important impact on diet quality. For example, Kennedy (2004) demonstrates that variety in certain selected energy-dense foods may contribute
} 
diversity and BMI, which is an important indicator of health status. Our analysis is based on individual Kosovar micro-data from 2012. The nutrition literature (e.g., Hatloy et al., 1998; Azadbakht et al., 2006; Darmon and Drewnowski, 2008; Rosinger et al., 2013) shows that consumption of diverse diets has a positive impact on achieving optimal BMI and better healthrelated outcomes. ${ }^{6}$ First, we estimate demand for diet diversity, using several different measures. Our first hypothesis is that household socio-economic status affects diet diversity - a more diverse diet indicates better food utilisation and thus, improved food security status. Second, we study the impact of diet diversity on individual BMI while controlling for a range of individual, household, and environmental factors. ${ }^{7}$ Our second hypothesis is that more diverse diet would help achieve optimal individual BMI which in turn is associated with better health-related outcomes. Thus, our second hypothesis implies an inverted-U shaped relationship between diet diversity measures and BMI.

This study is, to the best of our knowledge, the first attempt to evaluate diet quality and test the link between diet and BMI in a CEE country context using representative micro-data. ${ }^{8}$ We use an innovative empirical framework based on a sound theoretical model of household health production following Huffman and Rizov (2010). We find that diverse diet positively affects an individual's BMI in the lower quantiles of the BMI's distribution, it has no effect in the median of the distribution, and has significant negative effect on BMI in the upper quantiles of the distribution. Other control variables like gender, age, education, and lifestyle also significantly influence the individual BMI. The finding of an inverted-U shaped relationship between the diet diversity and BMI can have important implications for policies designed to prevent food insecurity and enhance healthy nutrition of the population.

The paper is organised as follows. In section 2 we present the theoretical framework underlying the empirical analysis outlined in section 3. Section 4 reports and discusses estimation results while section 5 concludes the paper.

to overweight and obesity. The issue for overweight and obesity is achieving energy balance which is harder to achieve with diets high in total fat and energy.

${ }^{6}$ However, some studies examining the association between diet diversity and obesity have led to inconsistent findings. Salehi-Abargouei et al. (2016) reviewed several studies using explicitly Dietary Diversity Score (DDS). Their metaanalysis showed that there was no significant association between DDS and BMI status, which may be due to use of different methods for assessing dietary intake and DDS. The authors recommend conducting well-designed prospective studies with similar approaches to assess DDS.

${ }^{7}$ Nuttall (2015) shows that BMI's use to estimate percentage of body fat and ultimately predict health-related outcomes is a rather crude approach. Even when some comorbidities are considered, the correlation of mortality rates with BMI should also take into consideration such factors as individual age, lifestyle and occupation, family history of diabetes, hypertension, and coronary heart disease, familial longevity, etc.

${ }^{8}$ Our analysis relates to studies on the socio-economic antecedents of diet diversity and food security conducted in a developing country context (e.g., Campbell, et al., 2010; Thorne-Lyman et al., 2010; Rosinger et al., 2013; Sturm et al., 2016). 
There is substantial evidence on the link between income and overweight and obesity, measured by BMI, at both the country and individual level. At the country level the link between income, measured as GDP per capita and BMI is depicted in Figure 1 showing a clear inverted-U shaped relationship: as countries become richer BMI first rises and at high income levels - declines. ${ }^{9} \mathrm{~A}$ similar relationship holds for a country over the stages of its economic development and at the individual level across income groups as shown in studies by Komlos and Baur (2004) and Lakdawalla et al. (2005). Therefore, the productive household models of health developed by Rosenzweig and Schultz (1982) and Grossman (2000) provide a useful theoretical background for the analysis of the link between economic choices and BMI. Huffman and Rizov (2010) building on the existing theory develop an empirical framework that explicitly models the link between food diet and BMI.

Figure 1 here

We set out the model by specifying an individual utility function

$$
U=U(D, C, B M I, L ; O) \text {. }
$$

Utility is determined by the food diet consumed, $D$; consumption of other goods (excluding food) and services, $C$; body-mass index, $B M I$ proxying for health status; ${ }^{10}$ leisure, $L$; and fixed characteristics, such as age, gender, education, and socio-economic background, $O$.

The individual has a BMI production function

$$
B M I=B(D, L ; O, \varepsilon),
$$

where $\varepsilon$ is the unobserved individual characteristics that affect the individual's BMI; such characteristics may include genetic factors. In large meta-population samples it is likely that $\varepsilon$ is randomly distributed, with a zero mean, and influences both younger and older population cohorts in a similar manner (e.g., Malis et al., 2005; Dolton and Xiao, 2017). Food consumption affects utility directly and indirectly, through BMI production, by providing energy, vitamins and minerals.

The individual has a budget constraint

$$
P_{D} D+P_{C} C=W(T-L)+N
$$

\footnotetext{
${ }^{9}$ There is evidence documented in several studies that 'optimal' BMI has been rising through time, since the beginning of the $20^{\text {th }}$ century and the trend has been accompanied by a decline in chronical diseases and an increase in longevity (Fogel, 1994; Nuttall, 2015). Fogel (1994) argues for the need to recognise a range of technological, socio-economic, and environmental factors affecting the acceleration in population's anthropometric parameters and life expectancy within a long-run dynamic framework.

${ }^{10}$ Nuttall (2015) discusses the evolution of the understanding on the link between BMI and health-related outcomes. Since about the beginning of the $20^{\text {th }}$ century measures based on weight and height both comprising BMI have been used to predict life expectancy for insurance purposes. Insurance data identified optimal BMI at which mortality was the lowest which is then referred to as 'ideal' BMI. This evidence implies an inverted U-shape relationship between $\mathrm{BMI}$ and health status whereas at low and high BMI values health is compromised.
} 
where $P_{D}$ and $P_{C}$ denote the prices of food $(D)$, and other goods and services $(C)$ respectively; $W$ is the wage rate per unit of time, $T$ is the fixed time endowment ( $T-L=$ work), and $N$ is the nonlabour income.

For an interior solution of the model, we substitute equation (2) into (1) and use the budget constraint (3). The individual chooses $D, L$ and $C$ by maximising his/her utility subject to the budget constraint. The utility maximisation problem can be written as

$$
\Lambda=U[D, C, B(D, L ; O, \varepsilon), L ; O]+\lambda\left(W T+N-P_{D} D-P_{C} C-W L\right),
$$

where $\lambda$ is the Lagrange multiplier representing the marginal utility of individual's full income. The first order conditions for an optimal solution are:

$$
\begin{aligned}
& U_{B} B_{D}+U_{D}=\lambda P_{D}, \\
& U_{B} B_{L}+U_{L}=\lambda W, \\
& U_{C}=\lambda P_{C}, \\
& W T+N=P_{D} D+P_{C} C+W L,
\end{aligned}
$$

where $U_{B}=\partial U / \partial B, B_{D}=\partial B / \partial D, U_{D}=\partial U / \partial D, B_{L}=\partial B / \partial L, U_{L}=\partial U / \partial L$ and $U_{C}=\partial U / \partial C$. For an interior solution, equations (5)-(8) yield the individual's optimal demand functions for $D, L$ and $C$ :

$$
\Phi^{*}=f_{\Phi}\left(P_{D}, P_{C}, W, N, O, \varepsilon_{\Phi}\right), \quad \Phi=D, L, C .
$$

Therefore, the demand for inputs into the BMI production function depends on the prices of the purchased inputs $\left(P_{D}, P_{C}\right)$, the wage rate $(W)$, non-labour income $(N)$, fixed factors $(O)$ and unobserved factors $(\varepsilon)$, which are assumed to have zero expected mean. After substituting the optimal demand functions $D^{*}$ and $L^{*}$ from equation (9) into the BMI production function (2), we obtain the individual's BMI supply function:

$$
B M I^{*}=B_{S}\left(P_{D}, P_{C}, W, N, O, \varepsilon_{B}\right) .
$$

Note that the BMI supply function (equation 10) is a reduced-form (behavioural) relationship based on the optimal individual decisions while the individual's BMI production function (equation 2) is a technology relationship. Equation (10) represents the solution to the first-order (KuhnTucker) conditions for the structural endogenous variables $(D, L, C)$ in terms of the exogenous factors which include wages, prices, and characteristics of the BMI production and utility functions. This is a common approach of transitioning to an empirical framework.

An alternative (structural) approach to the transition to an empirical framework that is particularly suitable for our purpose to estimate the impact of diet diversity on BMI can be implemented in two stages following Huffman and Rizov (2010). First, we estimate the demand function, equations (9) for diet diversity following Herzfeld et al. (2014), and, separately, for 
smoking as an important factor affecting both diet and BMI, and a wage equation to obtain a proxy of leisure demand. Second, we substitute the predicted values of diet diversity, propensity to smoke, and wage from the first stage in the technology equation (2), which, together with exogenous controls for the individual and household behaviour listed in vector $O$, becomes the BMI supply function:

$$
B M I^{*}=B_{S}^{*}\left(D^{*}, L^{*}, O, \varepsilon_{B}^{\prime}\right) .
$$

Equation (11) represents the link between diet quality (diversity) and health status (BMI) and is in the focus of our empirical analysis that follows. Additional advantage of the two stage procedure adopted is that it deals well with the possible endogeneity of explanatory variables used in the BMI supply equation. ${ }^{11}$ Specifically, we use in the second stage predicted values from the first stage, where as instruments are added appropriate exogenous variables following the relevant literature.

\section{$3 \quad$ Data and estimation strategy}

We analyse diet diversity of Kosovar households and its impact on individuals' BMI using the Household Budget Survey (HBS) data collected by the Kosovar Statistical Office. Our dataset consists of four seasonal rounds in 2012 which represent repeated cross-sections and do not form a panel. The survey provides detailed information on household incomes and expenditures on food and non-food goods and services. The HBS data also contains detailed information on quantities consumed by each household, location of the household, and its size. Individual household member characteristics such as age, education, and work status are also available. The 2012 total sample contains approximately 8,900 adult individuals. The information on food consumption is collected on a seven-day recall basis in four monthly waves, one for each of the four seasons. Importantly, data also contains anthropometric information on individual weight and height, and lifestyle patterns such as frequency and nature of physical activity, and tobacco smoking.

\subsection{Variable description}

There is a plethora of definitions and measurements of diet diversity in the literature. Hoddinott (1999), Kennedy (2004), and Carletto et al. (2013) offer a comprehensive overview of frameworks for measuring household diet quality (including diversity) and food security. Haines et al. (1999) and Azadbakht et al. (2006) advocate a dietary diversity score (DDS), which is based on the US Food Guide Pyramid and is an indicator of overall diet quality, as associated with various nutrient

\footnotetext{
11 In a recent paper Morales et al. (2016) address comprehensively in a simultaneous equation framework the endogeneity issues associated with estimating the determinants of obesity using rich U.S. panel data as they focus on the endogenous lifestyle and location choices. Given the limitations of our data and focus of our analysis on both the determinants of diet diversity and, in turn, the impact of diet on health status, proxied by BMI, we consider our twostage approach most appropriate.
} 
adequacy ratios, after adjusting for the effect of energy intake. ${ }^{12}$ Salehi-Abargouei et al. (2016) carry out a meta-analysis on the link between DDS and BMI and suggest that more studies are needed utilising various measures of diet diversity. In this paper we employ four diversity measures of household diet which emphasise different aspects and components of the diet: (i) Count Measure (CM) of food items, (ii) diversity measured by the Simpson Index (SI), (iii) diversity measured by the Entropy Index (EI), and (iv) Dietary Diversity Score (DDS) based on the US Food Guide Pyramid.

The number of food items consumed during a recall time period has been commonly used as an indicator of diet diversity (e.g., Jackson 1984; Kant 1996). The count measure, CM can be defined as a sum of dummy variables $Q_{i}$ taking value of 1 if a household consumes $i$-th food item in its basket and 0 otherwise: $C M=\sum Q_{i}$. This is a theoretically derived diet diversity measure based of an ordinal utility function. The next two measures, SI and EI, which are also theoretically derived have become popular in measuring diet diversity in the food economics literature (e.g., Theil and Finke, 1983; Thiele and Weiss, 2003; Herzfeld et al., 2014). The Simpson Index, SI also known as Berry Index is defined as $S I=1-\sum w_{i}^{2}$, where $w_{i}$ is the budget share of the $i$-th (disaggregated) food item in the total food expenditure (basket); SI is closely associated with the well-known Herfindahl-Hirschman Index (HHI). The Entropy Index, EI, which places greater weight on smaller shares and thus is especially sensitive to differences in the number of minor commodities in the consumption basket is defined as $E I=\sum w_{i} \log \left(1 / w_{i}\right)$.

In calculating the three diversity indices considered so far we use all of the 96 disaggregated food items available in the data, including less healthy, energy dense food items such as sugar, oil, etc. Unlike CM, both SI and EI take into account the relative quantity of each food item consumed. The formulation of SI and EI implies that diversity is higher when more food items are consumed in equal (quantity or expenditure) proportions.

We construct the dietary diversity score, DDS following Azadbakht et al. (2006) and using 70 disaggregated food items from five main groups - bread/grains, vegetables, fruits, meats and meat substitutes and dairy foods - according to the Food Guide Pyramid. Consequently the disaggregated food items were aggregated into 23 subgroups, which capture the dietary diversity across the main groups. The bread/grain group contains seven subgroups (refined bread, biscuits, macaroni, whole bread, cornflakes, rice, and refined meal). Two subgroups of fruits were created (fruit and fruit juice, berries and citrus) and vegetables were divided into seven subgroups (vegetables, potatoes,

\footnotetext{
${ }^{12}$ Kennedy (2004) proposes Healthy Eating Index (HEI) which is partly based in the US Food Guide Pyramid but also includes components based on aspects of the Dietary Guidelines. This index is highly information demanding and we were unable to use it due to lack of data.
} 
tomatoes, starchy vegetables, legumes, yellow vegetables, green vegetables). Four subgroups of meat (red meat, poultry, fish, and eggs) and three subgroups of dairy (milk, yoghurt, and cheese) were created.

In the first stage of our analysis we use two more dependent variables. A dummy variable indicating smoking takes a value of 1 if the individual is a smoker and 0 otherwise. The demand for leisure is determined by the price of time which is discussed later in section 3.2 following Huffman and Rizov (2010).

The second stage of our analysis focuses on the impact of diet diversity on individual BMI in Kosovo. ${ }^{13}$ Anthropometric studies suggest measurement of the physical dimensions and gross composition of the human body as the most powerful tools to determine the long-term individual nutrition and health status (Victora, 1992; Gibson, 2005; Neufeld and Osendarp, 2014). An added value of such indicators lays in their ability to discriminate between different physiological and biological factors (Gorstein et al., 1994). Poor nutritional status influences health and wellbeing through the life cycle from the prenatal period on into elder years (Cook and Frank, 2008). Therefore, anthropometric measures are defined as impact indicators for the purposes of food security analysis as they indicate the degree to which the food has been accessible, utilised, and converted into satisfactory nutrition (Reinhard and Wijayaratne, 2000). Figure 2 presents the BMI index distribution of Kosovar adults by gender; it is evident that men's mode BMI is much higher than women's and into the range of overweight category according to WHO's classification.

Figure 2 here

Descriptive statistics of the dependent variables discussed above and all explanatory variables as discussed in the theoretical section (components of vector $O$ ) and, in addition, regional dummies, proxing for prices, used in the first stage analysis are reported in the Appendix - Tables A.1, A.2, and A.3. The means of the variables of special interest - the diet diversity measures - are close to their respective medians, except for the Simpson Index, suggesting there is a room for improvement in diet diversity according to our measures used. In the Appendix Table A.4 we also present correlation matrix of the four diet diversity measures which demonstrates that the measures considered are quite highly correlated. Table 1 reports descriptive statistics of variables entering the second stage analysis based on the BMI supply equation.

Table 1 here

13 According to WHO (2014) the optimal BMI ranges from 18.5 to 25, where BMI lower than 18.5 indicates underweight, while higher than 25 BMI score indicates overweight; BMI above 30 indicates obesity status. 


\subsection{Estimation strategy}

Following our theoretical model, we estimate in the first stage the endogenous demand variables diet diversity, smoking, and leisure, proxied by the wage rate - all affecting BMI production and supply, and then use their predicted values in the second stage BMI supply equation.

\section{Diet diversity}

Theoretically, the diet diversity specification is based on standard demand analysis and extensions by Jackson (1984), Stewart and Harris (2005), and Herzfeld et al. (2014). We empirically implement the household diet diversity demand function following Herzfeld et al. (2014) and Cupák et al. (2016) by specifying an estimating equation where household diet diversity is explained by prices, controlled for by regional dummy variables, household income, and household characteristics (household size, composition, education level, and employment status), and production and consumption patterns in terms of household consuming own food production and food away from home. As controls we also add season and region dummy variable sets.

\section{Propensity of smoking}

We estimate propensity of smoking as a function of prices (regional dummy variables) and income as well as of individual characteristics listed in vector $O$. The literature on myopic addiction initiated by Pollack (1970) models smoking as a partial adjustment process where a lagged dependent variable represents the propensity of smoking which is carried over from period to period and its coefficient can be interpreted as an indicator of the strength of addiction. Because of the cross-sectional nature of our analysis and issues with availability of data we include a variable for physical activity capturing aspects of individual lifestyle patterns, thus, arguably, also capturing the variation in the degree of addiction among smokers. Furthermore, the rational addiction model of Becker and Murphy (1988) implies that the propensity of future smoking should be included in the regression as well. Due to lack of appropriate information in our data we are not able to estimate the model of propensity of smoking by fully controlling for rational addiction behaviour. Becker et al. (1991), however, suggest that the long-run responses obtained from both myopic and rational addiction models are similar.

\section{Leisure demand}

As an approximation of leisure demand we estimate a wage equation as in Huffman and Rizov (2010). Considering that our main goal is to analyse the link between diet diversity and BMI, an estimate of opportunity cost of time given that leisure is a normal good is a reasonable control for leisure demand. Wage equation is specified following Becker (1965) and is estimated following Heckman (1974). The predicted wage rate for all sampled individuals is used to control for leisure demand in the second-stage BMI supply equation. 
The wage equation is estimated using the Heckman selection model. The dependent variable in the wage equation is $\log$ of the wage rate and the explanatory variables are individual characteristics (as specified in vector $O$ ) plus seasonal and regional dummies. Number of adult household members, number of children in the household, and non-labour income, including remittances, and controls for constraints and incentives of an individual to undertake market employment are used as identifying variables, in the first step, selection equation. Regional fixed effects control for relative labour market conditions and prices of food and other omitted variables that differ by region.

\section{BMI supply}

In the second stage of our empirical analysis, we use the predicted values of diet diversity, propensity of smoking, and wage rate (leisure demand) to estimate the BMI supply function. The following are also included as explanatory variables: individual characteristics as specified in vector $O$, a variable controlling for physical activity and lifestyle, and dummies indicating urban areas and capital city location. ${ }^{14}$ The BMI supply equation (11) is first estimated by standard OLS regression. Considering our theoretical discussion and expectations of a non-linear, inverted-U shaped link between diet diversity and BMI, we also estimate BMI by quantile regression (QR) which forms the core of our estimation strategy. ${ }^{15}$

Given the cross-sectional nature of our data, to address concerns of endogeneity problems when estimating BMI supply equations we introduce the explanatory variables stepwise, one-byone, to check for stability of coefficients to changes in the specification. The procedure yields robust coefficients and gives us the confidence to conclude that our estimation strategy deals reasonably well with endogeneity problems. Furthermore, in equilibrium, it is reasonable to assume that factors affecting overweight and obesity are predetermined, that is, even though overweight and obesity may affect an individual's characteristics, an individual's characteristics (and other behavioural and environmental factors) determine obesity. Important in this relationship are the lags of the effects. Therefore, we assume here that the time lag of the overweight and obesity effect on an individual's characteristics is much longer than the lag of individual characteristics' effects on overweight and obesity.

\footnotetext{
14 The importance of location for the overweight and obesity status has been explicitly recognised in recent studies by Morales et al. (2016) and Raftopoulou (2017) as the former paper models the location decision as endogenous choice. In our cross-sectional analysis regional dummies are exogenous controls as well as the physical activity variable is which we consider as representing medium-term (at least) lifestyle patterns associated with individuals' working lives given the specific survey question in our data.

${ }^{15}$ In a different but related context Dolton and Xiao (2017) study the intergenerational transmission of BMI within a quantile regression framework and find substantial differences across the distribution.
} 


\section{$4 \quad$ Estimation results}

\subsection{First stage results: Obtaining predicted values}

\section{Diet diversity}

Detailed results from estimating OLS models with each of the four measures of diet diversity (CM, SI, EI, DDS) as dependent variable are reported in the Appendix, Table A.5. The results are quite similar across the four estimated equations with some differences in the DDS specification compared to the rest. Household income is an important determinant of diet diversity across all diversity measures as well as the gender and education are - men exhibit less diverse diet while higher education is associated with more diverse diet. Further, in urban areas households consume more diverse diets.

The consumption of own food production and consumption of food away from home appear to negatively affect only the DDS measure. There is also seasonal variation in diet diversity as in the winter and summer seasons diversity is lower when DDS measure is considered. Again according to DDS larger households have less diverse diets while households with young children consume more diverse diets.

\section{Propensity of smoking}

Detailed results of the estimation of the Probit model are reported in the Appendix, Table A.6. We find that higher income leads to higher propensity of smoking which is also true for the urban population compared to its rural counterpart, and for men compared to women. Individuals with higher education are less likely to smoke while there is an inverted U-shape relationship between propensity of smoking and age.

\section{Leisure demand}

Full estimation results are reported in the Appendix, Table A.7. We find from the second stage of the Heckman model that men and better educated individuals earn higher wage and thus have higher opportunity cost of time. There is an inverted-U shaped relationship between wage and age while wages are uniformly higher in the urban areas.

\subsection{Second stage results: The link between diet diversity and BMI}

In Tables 2, 3, 4, and 5 we report the main (second stage) estimation results from the OLS and conditional quantile regressions for each of the four (predicted) diet diversity measures. We focus on five quantiles of the BMI distribution $(\mathrm{Q}=0.10, \mathrm{Q}=0.20, \mathrm{Q}=0.50, \mathrm{Q}=0.80$, and $\mathrm{Q}=0.90)$ (monotonically) representing the three main categories of individual's weight (and health) status underweight, normal weight, and overweight/obese. The explanatory variable of main interest in each specification is the predicted diet diversity measure. The most important message from our 
estimation results is that for all four diet diversity measures there is a non-linear, inverted-U shaped relationship between diet diversity and BMI which is evident from the QR analysis. ${ }^{16}$ In the underweight quantiles the relationship is positive and statistically significant suggesting that more diverse diet is associated with higher BMI which indicates a better health status in this range of the BMI distribution. In the median quantile representing individuals with normal weight the relationship between diet and BMI is positive but not statistically significant. In the overweight and obese quantiles of the BMI distribution, where the risk or diabetes and cardio vascular despises is higher, we find statistically significant negative relationship between diet diversity and BMI indicating again that more diverse diet leads to better health status by supporting optimal (lower) BMI. In terms of measured impact, considering the whole original distribution, one standard deviation increase in diet diversity leads to up to $2.3 \%$ increase in BMI of the underweight individuals and around $1.5 \%$ reduction in BMI of the obese individuals. ${ }^{17}$

Tables 2, 3, 4, 5 here

The rest of the estimation results associated with individual demographic characteristics are in line with existing theories and empirical evidence (e.g., Komlos and Baur, 2004; Lakdawalla et al., 2005; Huffman and Rizov, 2010). Specially, men are characterised by higher BMI while there is a general inverted U-shape age effect in the sample containing both adult men and women. Physical activity and proactive lifestyle affect positively the BMI up to the median of the distribution while beyond this point there is no statistically significant effect. While (general) education appears to have an overall negative effect on BMI in the median quantile, in the obese category $(\mathrm{Q}=0.8$ and $\mathrm{Q}=0.9$ ) it has no statistically significant effect. The results on physical activity and education confirm that obesity status is determined not only by environmental and socio-economic factors but also by genetic traits (e.g., Nuttall, 2015). The demand for leisure does not appear to significantly impact on BMI while smoking has significant negative association with BMI in all parts of the distribution. Urban areas, relative to rural ones, seem to contain more individuals from both extremes of the BMI distribution - underweight and obese - but when the capital city location is considered the individuals residing there seem to have more balanced (less dispersed) BMI distribution - a finding suggesting that the food security situation is better in the capital compared to the rest of the country.

\footnotetext{
16 The $\mathrm{Q}=0.1-\mathrm{Q}=0.9$ quantile differences in the diet diversity coefficients are statistically significant at $5 \%$ level or better as confirmed by Wald test results which are available on request.

${ }^{17}$ The standard deviations of the diet diversity measures are around $20 \%$ of the respective means (with the exception of SI for which standard deviation is rather small) suggesting a potential scope for improvement in population's diet diversity. Thus, we can conclude that the estimated diet diversity effect is of economic importance. Furthermore, as discussed earlier more diverse diets are generally associated with better food security status, particularly in terms of access and utilisation of food. Consequently, more diverse diet and better food security status are associated with better health-related outcomes (e.g., Kennedy, 2004; Campbell, et al., 2010; Thorne-Lyman et al., 2010).
} 
Overall we can conclude that the four specifications containing the four different measures of diet diversity produced similar results in our Kosovar population. Observationally and statistically, the results from the EI and DDS specifications appear most similar in terms of magnitude of estimated effects.

As a robustness check, we estimate BMI supply equations, by OLS, separately for men and women. These results are reported in the Appendix, Table A.8. The results suggest that at the mean of the BMI distribution there are no important differences in diet diversity coefficients across the four measures by gender. However, there are significant differences in the estimated effects of the rest of the variables across genders. Better education helps reduce BMI only in the female sample. The effect of smoking on BMI is also stronger for women compared to men. Interestingly, intensive physical activity only positively affects men's BMI possibly due to the relative increase in their muscular mass which disproportionately affects the BMI measure.

\section{Conclusion}

Food insecurity in Kosovo is revealed by the significant income effects estimated and the significant dispersion of measures of dietary diversity computed from household expenditure microdata as well as by the dispersion of the anthropometric indicator, BMI. Building on a household model of health production we devise a two-stage estimation strategy to analyse the antecedents of diverse (balanced) diet and its impact on BMI indicating an individual's health status. From our first-stage estimation results concerning four measures of diet diversity we can conclude that Kosovars are significantly exposed to food security risks caused mainly by low incomes and low education as the risks are highest in the rural areas.

Our second-stage BMI supply estimation results suggest that diet diversity, measured by four different measures, has an important role to play in tackling underweight and obesity problems both associated with food and nutritional insecurity. Given that underweight and obesity problems signal ill-health hazard, policies facilitating more diverse, better quality diet and healthy lifestyles may have important positive impact on public health in Kosovo.

The main limitations of the study are in terms of the cross-sectional nature of the data used and the lack of direct health status information which could have allowed testing for the entire link between diet, BMI, and health-related outcomes. Another data limitation is the lack of information for constructing a (direct) diet quality measure which is sometimes found to generate result different from the ones generated by diet diversity measures. In terms of our finding that all four diversity measures we used generated similar results we need to point out that those are pertinent to Kosovo only and similar analysis should be carried out in other geographic and socio-economic contexts 
before confirming the relative importance of various diet diversity measures. The above stated limitations can be taken as a basis for fruitful future research on the link between diet and health. 


\section{References}

Ali, S.M. and Lindström, M. (2006). Socioeconomic, psychosocial, behavioural, and psychological determinants of BMI among young women: differing patterns for underweight and overweight/obesity. The European Journal of Public Health, 16(3): 324-330. https://doi.org/10.1093/eurpub/cki187.

Azadbakht, L., Mirmiran, P., Esmaillzadeh, A., and Azizi, F. (2006). Dietary diversity score and cardiovascular risk factors in Tehranian adults. Public Health Nutrition, 9(6): 728-736. http://dx.doi.org/10.1079/PHN2005887.

Becker, G.S. (1965). A theory of the allocation of time. The Economic Journal, 75(299): 493-517. http://dx.doi.org/10.2307/2228949.

Becker, G.S. and Murphy, K.M. (1988). A theory of rational addiction. Journal of Political Economy, 96 (4): 675-700. http://dx.doi.org/10.1086/261558.

Becker, G.S., Grossman, M. and Murphy, K.M. (1991). Rational addiction and the effect of price on consumption. American Economic Review, 81(2): 237-241.

Braha, K., Rajcaniova, M. and Qineti, A. (2015). Spatial Price Transmission and Food Security: The case of Kosovo. Paper presented in AIEAA (Italian Association of Agricultural and Applied Economics) Fourth Congress, June 11-12, Ancona, Italy.

Campbell, A.A., de Pee, S., Sun, K., Kraemer, K., Thorne-Lyman, A., Moench-Pfanner, R., Sari, M., Akhter, N., Bloem, M.W., Semba, R,D. (2010). Household rice expenditure and maternal and child nutritional status in Bangladesh. Journal of Nutrition, 140(1):189S-194S. http://dx.doi.org/10.3945/jn.109.110718.

Carletto, C., Zezza, A., and Banerjee, R. (2013). Towards better measurement of household food security: Harmonizing indicators and the role of household surveys. Global Food Security, 2: 30-40. http://dx.doi.org/10.1016/j.gfs.2012.11.006.

Clapp, J. and Cohen, M. (2009). The global food crisis: Governance, challenges and opportunities. Waterloo: Wilfrid Laurier University Press.

Cook, J. T. and Frank, D. A. (2008). Food security, poverty, and human development in the United

States. Annals of the New York Academy of Sciences, 1136(1): 193-209. http://dx.doi.org/10.1196/annals.1425.001.

Cupák, A., Pokrivčák, J. and Rizov, M. (2016). Diversity of food consumption in Slovakia. Politická ekonomie, 64 (5): 608-626. ISSN 0032-3233.

Darmon, N. and Drewnowski. A. (2008). Does social class predict diet quality? The American Journal of Clinical Nutrition, 87 (5): 1107-1117. 
Dolton, P. and Xiao, M. (2017). The intergenerational transmission of body mass index across countries. Economics and Human Biology, 24: 140-152. http://dx.doi.org/10.1016/j.ehb.2016.11.005.

Duval, L. and Wolff, F. (2013). The consumption-enhancing effect of remittances: Evidence from Kosovo. The wiiw Balkan Observatory, Working paper No. 107.

FAO (2015). The State of Food Insecurity in the World 2015. Meeting the 2015 international hunger targets: taking stock of uneven progress. Rome: FAO.

Fogel, R. (1994). Economic growth, population theory, and physiology: The bearing of long-term processes on the making of economic policy. American Economic Review, 84(3): 369-395.

Gibson, R.S. (2005). Principles of nutritional assessment. Oxford university press, USA.

Gorstein, J., Sullivan, K., Yip, R., De Onis, M., Trowbridge, F., Fajans, P. and Clugston, G. (1994). Issues in the assessment of nutritional status using anthropometry. Bulletin of the World Health Organization, 72 (2): 273-283.

Grossman, M. (2000). The Human Capital Model. In A.J. Cutler and J.P. Newhouse, Handbook of Health Economics, Vol. 1A, New York, NY: Elsevier, pp. 248-408.

Gutiérrez-Fisac, J.L., Rodríguez Artalejo, F., Guallar-Castillon, P., Banegas Banegas, J. R. and del Rey Calero, J. (1999). Determinants of geographical variations in body mass index (BMI) and obesity in Spain. International Journal of Obesity, 23(4): 342-347. http://dx.doi.org/10.1038/sj.ijo.0800823.

Haines PS, Siega-Riz AM, Popkin BM. (1999). The Diet Quality Index revised: a measurement instrument for populations. Journal of the American Dietetic Association, 99: 697-704. http://dx.doi.org/10.1016/S0002-8223(99)00168-6.

Hatloy, A., Torheim, L. E. and Oshaug, A. (1998). Food variety: a good indicator of nutritional adequacy of the diet. A case study from an urban area in Mali, West Africa. European Journal of Clinical Nutrition, 52 (12): 891-898. http://dx.doi.org/10.1038/sj.ejcn.1600662.

Heckman, J. (1974). Shadow prices, market wages, and labor supply. Econometrica, 42 (4): 679694. http://dx.doi.org/10.2307/1913937.

Herzfeld, T., Huffman, S. and Rizov, M. (2014). The dynamics of food, alcohol and cigarette consumption in Russia during transition. Economics and Human Biology, 13 (March): 128143. http://dx.doi.org/10.1016/j.ehb.2013.02.002.

Hoddinott, J. (1999). Choosing outcome indicators of household food security, International Food Policy Research Institute (IFPRI), Washington D.C. 
Huffman, S. and Rizov M. (2007). Determinants of obesity in transition economies: The case of Russia. Economics and Human Biology, 5(3): 379-391. http://dx.doi.org/10.1016/j.ehb.2007.07.001.

Huffman, S. and Rizov, M. (2010). The rise of obesity in transition: Theory and empirical evidence from Russia. Journal of Development Studies, 46(3): 574-594. http://dx.doi.org/10.1080/00220380903383230.

Humphriesa, D.L., Deardenb, K.A., Crookstonc, B.T., Woldehannad, T., Pennye, M.E., Behrmanf, J.R. (2017). Household food group expenditure patterns are associated with child anthropometry at ages 5, 8 and 12 years in Ethiopia, India, Peru and Vietnam. Economics and Human Biology, 26: 30-41. http://dx.doi.org/10.1016/j.ehb.2017.02.001.

Jackson, L. (1984). Hierarchic demand and the Engel curve for variety. The Review of Economics and Statistics, 66 (1): 8-15. http://dx.doi.org/10.2307/1924690.

Kant, A.K, Schatzkin, A., and Ziegler, R.G. (1995). Dietary diversity and subsequent cause of specific mortality in the NHANES I epidemiologic follow up study. Journal of the American College of Nutrition, 14:233-238. http://dx.doi.org/10.1080/07315724.1995.10718501.

Kant, A.K. (1996). Indexes of overall diet quality: a review. Journal of American Dietetic Association, 96(8): 785-791. http://dx.doi.org/10.1016/S0002-8223(96)00217-9.

Kennedy, E. (2004). Dietary diversity, diet quality, and body weight regulation. Nutrition Reviews, 62: S78-81. http://dx.doi.org/10.1111/j.1753-4887.2004.tb00093.x.

Kleiser, C., Rosario, A. S., Mensink, G. B., Prinz-Langenohl, R. and Kurth, B. M. (2009). Potential determinants of obesity among children and adolescents in Germany: Results from the cross-sectional KiGGS Study. BMC Public Health, 9:46 (14 pages). http://dx.doi.org/10.1186/1471-2458-9-46.

Knai, C., Suhrcke, M., and Lobstein, T. (2007). Obesity in Eastern Europe: an overview of its health and economic implications. Economics and Human Biology, 5(3): 392-408. http://dx.doi.org/10.1016/j.ehb.2007.08.002.

Komlos, J. and Baur, M., 2004. From the tallest to (one of) the fattest: the enigmatic fate of the American population in the 20th century. Economics and Human Biology, 2: 57-74.

Kortt, M.A. and Dollery, B. (2011). Association between body mass index and health-related quality of life among an Australian sample. Clinical Therapeutics, 33(10): 1466-1474. http://dx.doi.org/10.1016/j.ehb.2003.12.006.

Lakdawalla, D., Philipson, T., and Bhattacharya, J. (2005). Welfare-enhancing technological change and the growth of obesity. American Economic Review, 95: 253-257. http://dx.doi.org/10.1257/000282805774670266. 
MAFRD (Ministry of Agriculture, Forestry and Rural Development) (2014). Green Report 2014. Prishtina, Kosovo. Available at ks.net/repository/docs/56917_161214_GR_2014_ENG_Final_Printed_Version.pdf.

Malis, C., Rasmussen, E., Poulsen, P., Petersen, I., Christensen, K., Beck-Nielsen, H., Astrup, A. and Vaag, A. (2005). Total and regional fat distribution is strongly influenced by genetic factors in young and elderly twins. Obesity: A Research Journal, 13 (12): 2139-2145. http://dx.doi.org/10.1038/oby.2005.265.

McDonough, C., Dunkley, A.J., Aujla, N., Morris, D., Davies, M.J., and Khunti, K. (2013). The association between body mass index and health-related quality of life: Influence of ethnicity on this relationship. Diabetes, Obesity \& Metabolism, 15(4): 342-348. http://dx.doi.org/10.1111/dom.12033.

McMichael, P. and Schneider, M. (2011). Food Security Politics and the Millennium Development $\begin{array}{lllll}\text { Goals. } & \text { Third } & \text { World } & \text { Quarterly, }\end{array}$ http://dx.doi.org/10.1080/01436597.2011.543818.

Moon, W., Florkowski, W. J., Beuchat, L. R., Resurreccion, A. V., Paraskova, P., Jordanov, J., and Chinnan, M. S. (2002). Demand for food variety in an emerging market economy. Applied Economics, 34(5): 573-581. http://dx.doi.org/10.1080/00036840110037863.

Morales, L.F., Gordon-Larsen, P. and Guilkey, D. (2016). Obesity and health-related decisions: An empirical model of the determinants of weight status across the transition from adolescence to young adulthood. Economics and Human Biology, 23: 46-62. http://dx.doi.org/10.1016/j.ehb.2016.06.003.

Neufeld, L.M. and Osendarp, S.J.M. (2014). Global, regional and country trends in underweight and stunting as indicators of nutrition and health of populations. In International Nutrition: Achieving Millennium Goals and Beyond. Karger Publishers.

Nuttall, F.Q. (2015). Obesity, BMI, and health: A Critical Review. Nutrition Research, 50(3): 117128

Osmani, F., Gorton, M. and White, J. (2013). Agricultural households, poverty and the rural labour market in Kosovo. Post-Communist Economies, 25(2): 241-252. http://dx.doi.org/10.1080/14631377.2013.787756.

Pollack, R.A. (1970). Habit formation and dynamic demand functions. Journal of Political Economy, 78 (4): 745-763. http://dx.doi.org/10.1086/259667.

Raftopoulou, A. (2016). Geographic determinants of individual obesity risk in Spain: A multilevel Approach. Economics and Human Biology, 24: 185-193. http://dx.doi.org/10.1016/j.ehb.2016.12.001. 
Reinhard, I. and Wijeratne, K.B.S. (2000). The use of stunting and wasting as indicators for food insecurity and poverty. Poverty Impact Monitoring Unit, Working Paper 27.

Rosenzweig, M.R. and Schultz, T.P. (1982). The behavior of mothers as inputs to child health: The determinants of birth weight, gestation, and rate of fetal growth. In V.R. Fuchs, (Ed.), Economic Aspects of Health, National Bureau of Economic Research, The University of Chicago Press, pp. 53-92.

Rosinger, A., Tanner, S., and Leonard, W.R. (2013). Precursors to overnutrition: The effects of household market food expenditures on measures of body composition among Tsimane' adults in lowland Bolivia. Social Science and Medicine, 92: 53-60. http://dx.doi.org/10.1016/j.socscimed.2013.05.022.

Salehi-Abargouei, A., Akbari, F., Bellissimo, N., and Azadbakht, L. (2016). Dietary diversity score and obesity: a systematic review and meta-analysis of observational studies. European Journal of Clinical Nutrition, 70(1): 1-9. http://dx.doi.org/10.1038/ejen.2015.118.

Sen, K. and Kirkpatric, C. (2011). A diagnostics approach to economic growth and employment policy in low income economies: The case of Kosovo. Journal of International Development, 23(1): 132-154. http://dx.doi.org/10.1002/jid.1659.

Sirotin, N., Hoover, D., Segal-Isaacson, C. J., Shi, Q., Adedimeji, A., Mutimura, E., and Anastos, K. (2012). Structural determinants of food insufficiency, low dietary diversity and BMI: a cross-sectional study of HIV-infected and HIV-negative Rwandan women. BMJ Open, 2(2): e000714. http://dx.doi.org/10.1136/bmjopen-2011-000714.

Smith, L., Obeid, A., and Jensen, H. (2000). The geography and causes of food insecurity in developing countries. Agricultural Economics, 22: 199-215. http://dx.doi.org/10.1111/j.1574-0862.2000.tb00018.x.

Stewart, H. and Harris, M. (2005). Obstacles to overcome in promoting dietary variety: The case of vegetables. Review of Agricultural Economics, 27(1): 21-36. http://dx.doi.org/10.1111/j.1467-9353.2004.00205.x.

Sturm, R., Patel, D., Alexander, E., and Paramanund, J. (2016). Seasonal cycles in food purchases and changes in BMI among South Africans participating in a health promotion programme. $\begin{array}{llll}\text { Public Health } \quad \text { and } & \text { 2838-2843. }\end{array}$ http://dx.doi.org/10.1017/S1368980016000902.

Swinnen, J. and Van Herck, K. (2011). Food security and transition regions. Rome: FAO. Available at http://www.ebrd.com/downloads/research/essay/foodsecurity.pdf.

Theil, H. and Finke, R. (1983). The consumer's demand for diversity. European Economic Review, 23 (3): 395-400. http://dx.doi.org/10.1016/0014-2921(83)90039-9. 
Thiele, S. and Weiss, C. (2003). Consumer demand for food diversity: Evidence for Germany. Food Policy, 28 (2): 99-115. http://dx.doi.org/10.1016/S0306-9192(02)00068-4.

Thomas, D. and Frankenberg, E. (2002). Health, nutrition and prosperity: A microeconomic perspective. Bulletin of the World Health Organization, 80(2): 106-113.

Thorne-Lyman,A.L., Valpiani, N., Sun, K., Semba, R.D., Klotz, C.L., Kraemer, K., Akhter, N., de Pee, S., Moench-Pfanner. R., Sari, M., and Bloem, M.W. (2010). Household dietary diversity and food expenditures are closely linked in rural Bangladesh, increasing the risk of malnutrition due to the financial crisis. Journal of Nutrition, 140(1): 182S-188S. http://dx.doi.org/10.3945/jn.109.110809.

UNDP (United Nations Development Programme) (2014). Kosovo Human Development Report 2014. Available at http://hdr.undp.org/sites/default/files/khdr2014english.pdf.

Victora, C.G. (1992). The association between wasting and stunting: an international perspective. The Journal of Nutrition, 122(5): 1105-1110.

WHO (World Health Organisation) (2014) The International Classification of adult underweight, overweight and obesity according to BMI. Available at http://apps.who.int/bmi/index.jsp?introPage=intro_3.html.

World Bank (2015). Kosovo Country Snapshot. Available at http://www.worldbank.org/content/dam/Worldbank/document/eca/Kosovo-Snapshot.pdf.

World Bank/KAS (2011) Consumption poverty in the Republic of Kosovo in 2009. [Online]. Available at http://siteresources.worldbank.org/INTKOSOVO/Resources/Kosovo_Poverty_for_web_eng .pdf. 
Figure 1: Scatter plot of overweight and economic development across countries

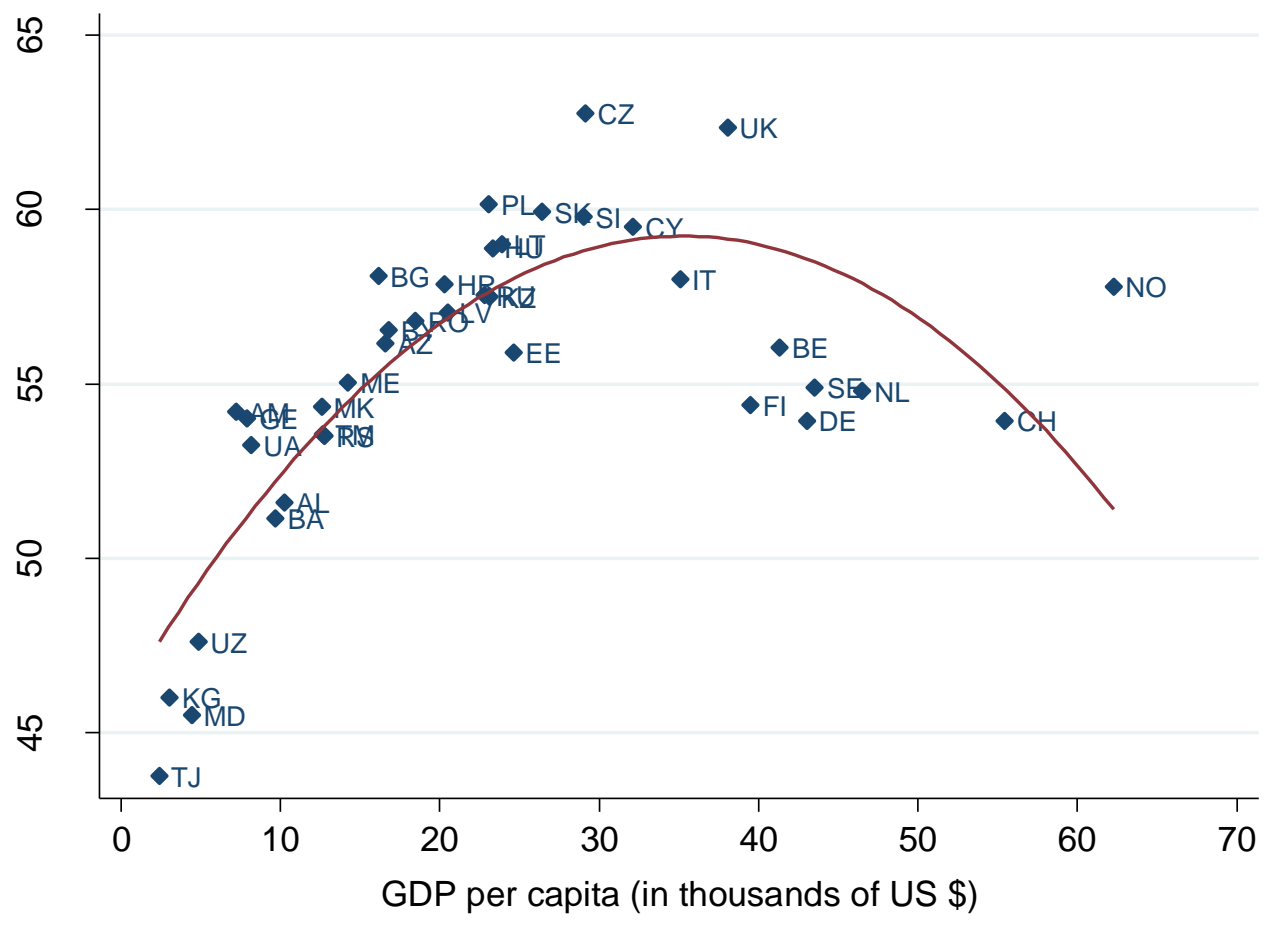

Source: WHO and World Bank data, averaged over the 2010-14 period; own processing 
Figure 2: Distribution of the BMI of Kosovar adults by gender

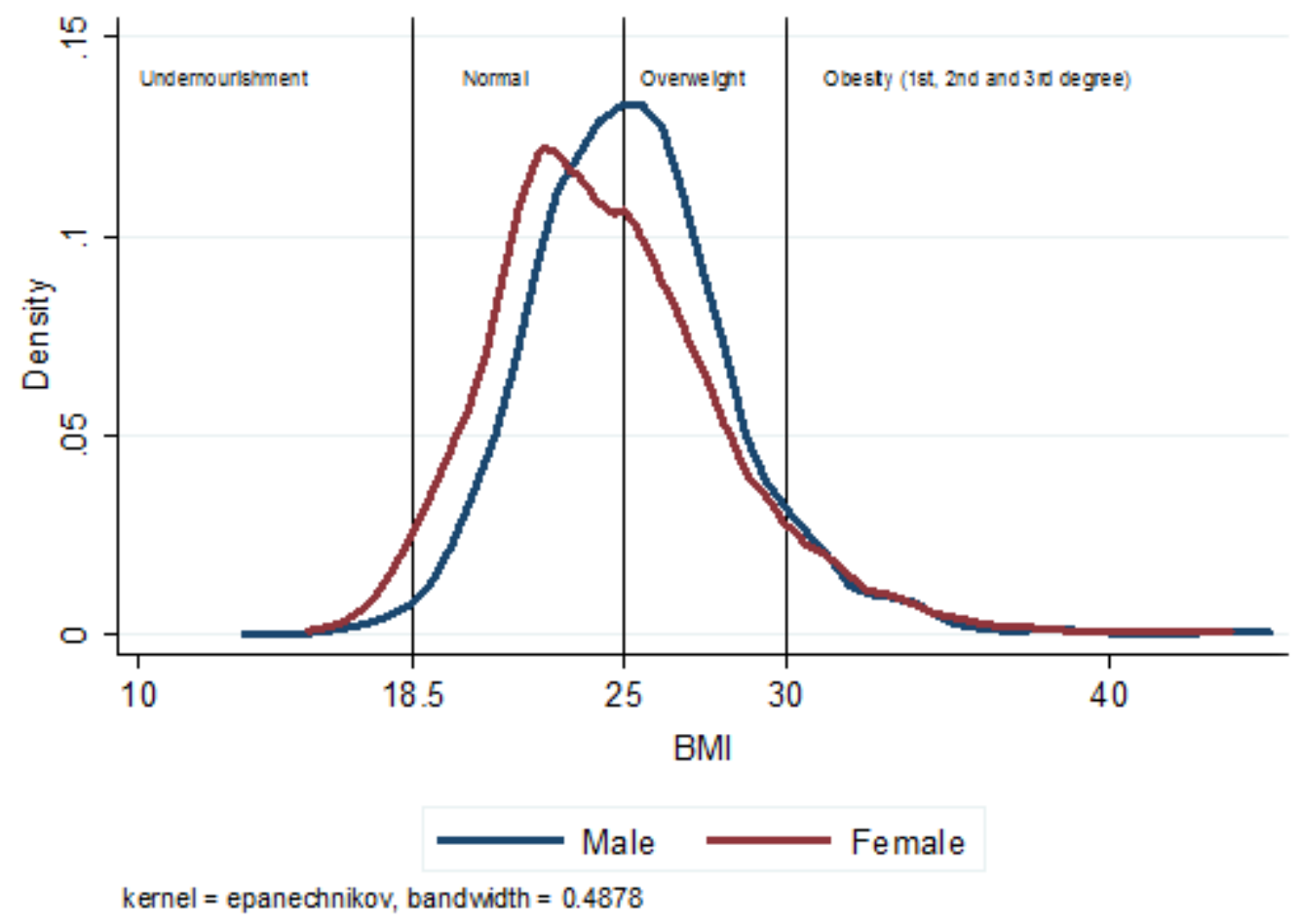

Note: Outliers (1\%) in the BMI were trimmed.

Source: HBS data of KAS, own processing 
Table 1 Descriptive statistics for the second stage BMI equation

\begin{tabular}{|c|c|c|c|c|c|}
\hline Variable & $\mathrm{N}$ & Mean & SD & Min & Max \\
\hline Body mass index & 8,902 & 24.91 & 3.50 & 13.73 & 44.38 \\
\hline Count Measure (predicted) & 8,739 & 28.96 & 6.88 & 2.15 & 46.57 \\
\hline Simpson Index (predicted) & 8,733 & 0.91 & 0.03 & 0.78 & 0.98 \\
\hline Entropy Index (predicted) & 8,733 & 2.87 & 0.27 & 1.75 & 3.55 \\
\hline Dietary Diversity Score (predicted) & 8,739 & 6.48 & 1.42 & -0.57 & 9.56 \\
\hline Dummy: Male & 8,916 & 0.50 & 0.50 & 0.00 & 1.00 \\
\hline Dummy: Completed higher education & 8,916 & 0.09 & 0.29 & 0.00 & 1.00 \\
\hline Dummy: Completed secondary education & 8,916 & 0.44 & 0.50 & 0.00 & 1.00 \\
\hline Dummy: Completed primary education & 8,916 & 0.46 & 0.50 & 0.00 & 1.00 \\
\hline Age & 8,916 & 41.05 & 17.06 & 18.00 & 103.00 \\
\hline Wage in euro/hour (predicted) & 8,916 & 7.31 & 0.46 & 5.15 & 8.63 \\
\hline Dummy: Daily propensity of smoking (predicted) & 8,916 & 0.20 & 0.15 & 0.00 & 0.60 \\
\hline Daily physical activity score & 8,916 & 2.22 & 0.72 & 1.00 & 4.00 \\
\hline Dummy: Urban area & 8,916 & 0.50 & 0.50 & 0.00 & 1.00 \\
\hline Dummy: Capital city & 8,916 & 0.17 & 0.37 & 0.00 & 1.00 \\
\hline
\end{tabular}


Table 2: OLS and QR estimates of the second stage BMI equation (CM)

\begin{tabular}{|c|c|c|c|c|c|c|}
\hline \multirow[b]{2}{*}{ Variable } & \multirow[b]{2}{*}{ OLS } & \multicolumn{5}{|c|}{ Quantile } \\
\hline & & 0.10 & 0.20 & 0.50 & 0.80 & 0.90 \\
\hline \multirow[t]{2}{*}{ Count Measure (predicted) } & -0.000 & $0.002^{* * *}$ & $0.001^{* *}$ & -0.000 & $-0.001^{*}$ & $-0.001^{* *}$ \\
\hline & $(0.000)$ & $(0.000)$ & $(0.000)$ & $(0.000)$ & $(0.000)$ & $(0.000)$ \\
\hline \multirow[t]{2}{*}{ Dummy: Male } & $0.071^{* * *}$ & $0.081^{* * *}$ & $0.075^{* * *}$ & $0.069^{* * * *}$ & $0.077^{* * *}$ & $0.078^{* * *}$ \\
\hline & $(0.006)$ & $(0.010)$ & $(0.007)$ & $(0.006)$ & $(0.008)$ & $(0.012)$ \\
\hline \multirow[t]{2}{*}{ Dummy: Completed higher education } & $-0.023^{*}$ & $0.037^{*}$ & -0.020 & $-0.040^{* * *}$ & -0.028 & 0.000 \\
\hline & $(0.012)$ & $(0.021)$ & $(0.015)$ & $(0.013)$ & $(0.018)$ & $(0.024)$ \\
\hline \multirow[t]{2}{*}{ Dummy: completed secondary education } & -0.010 & 0.014 & -0.012 & $-0.015^{* *}$ & -0.011 & -0.001 \\
\hline & $(0.006)$ & $(0.010)$ & $(0.008)$ & $(0.006)$ & $(0.009)$ & $(0.012)$ \\
\hline \multirow[t]{2}{*}{ Age } & $0.016^{* * *}$ & $0.018^{* * *}$ & $0.016^{* * *}$ & $0.014^{* * *}$ & $0.018^{* * *}$ & $0.021^{* * *}$ \\
\hline & $(0.001)$ & $(0.002)$ & $(0.001)$ & $(0.001)$ & $(0.002)$ & $(0.002)$ \\
\hline \multirow[t]{2}{*}{ Age squared } & $-0.014^{* * *}$ & $-0.017^{* * *}$ & $-0.014^{* * *}$ & $-0.012^{* * * *}$ & $-0.015^{* * *}$ & $-0.019^{* * *}$ \\
\hline & $(0.001)$ & $(0.002)$ & $(0.001)$ & $(0.001)$ & $(0.002)$ & $(0.002)$ \\
\hline \multirow[t]{2}{*}{ Wage (predicted) } & -0.003 & $-0.044^{* *}$ & 0.004 & 0.015 & -0.004 & -0.032 \\
\hline & $(0.012)$ & $(0.020)$ & $(0.015)$ & $(0.013)$ & $(0.018)$ & $(0.025)$ \\
\hline \multirow{2}{*}{$\begin{array}{l}\text { Dummy: Daily propensity of smoking } \\
\text { (predicted) }\end{array}$} & $-0.151^{* * * *}$ & $-0.132^{* * *}$ & $-0.134^{* * * *}$ & $-0.152^{* * * *}$ & $-0.187^{* * * *}$ & $-0.188^{* * * *}$ \\
\hline & $(0.020)$ & $(0.033)$ & $(0.025)$ & $(0.021)$ & $(0.028)$ & $(0.041)$ \\
\hline \multirow[t]{2}{*}{ Daily physical activity } & $0.007^{* * *}$ & $0.006^{*}$ & $0.009^{* * *}$ & $0.010^{* * *}$ & 0.004 & 0.003 \\
\hline & $(0.002)$ & $(0.003)$ & $(0.002)$ & $(0.002)$ & $(0.003)$ & $(0.004)$ \\
\hline \multirow[t]{2}{*}{ Dummy: Urban area } & 0.004 & $-0.017^{* * *}$ & $-0.012^{* * *}$ & 0.001 & $0.013^{* * *}$ & $0.018^{* * *}$ \\
\hline & $(0.003)$ & $(0.005)$ & $(0.004)$ & $(0.003)$ & $(0.004)$ & $(0.006)$ \\
\hline \multirow[t]{2}{*}{ Dummy: Capital city } & -0.000 & $0.021^{* * *}$ & $0.012^{* * *}$ & -0.001 & $-0.013^{* * *}$ & $-0.019^{* * *}$ \\
\hline & $(0.003)$ & $(0.005)$ & $(0.004)$ & $(0.003)$ & $(0.004)$ & $(0.007)$ \\
\hline \multirow[t]{2}{*}{ Constant } & $2.855^{* * *}$ & $2.924^{* * * *}$ & $2.716^{* * *}$ & $2.768^{* * * *}$ & $2.938^{* * *}$ & $3.131^{* * * *}$ \\
\hline & $(0.062)$ & $(0.105)$ & $(0.078)$ & $(0.067)$ & $(0.091)$ & $(0.126)$ \\
\hline (Pseudo) $\mathrm{R}^{2}$ & 0.242 & 0.140 & 0.140 & 0.153 & 0.130 & 0.124 \\
\hline $\mathrm{N}$ & 8,725 & 8,725 & 8,725 & 8,725 & 8,725 & 8,725 \\
\hline
\end{tabular}

Note: The dependent variable is $\log (\mathrm{BMI})$. Outliers $(1 \%)$ in the BMI were trimmed. Robust standard errors are presented in parentheses. Primary education is the reference category for the education dummy set. ${ }^{*} p<0.10,{ }^{* * *} p<$ $0.05,{ }^{* * *} p<0.01$. 
Table 3: OLS and QR estimates of the second stage BMI equation (SI)

\begin{tabular}{|c|c|c|c|c|c|c|}
\hline \multirow[b]{2}{*}{ Variable } & \multirow[b]{2}{*}{ OLS } & \multicolumn{5}{|c|}{ Quantile } \\
\hline & & 0.10 & 0.20 & 0.50 & 0.80 & 0.90 \\
\hline \multirow[t]{2}{*}{ Simpson Index (predicted) } & -0.049 & $0.367^{* * *}$ & $0.132^{*}$ & -0.056 & $-0.186^{* *}$ & $-0.288^{* *}$ \\
\hline & $(0.062)$ & $(0.107)$ & $(0.079)$ & $(0.063)$ & $(0.088)$ & $(0.131)$ \\
\hline \multirow[t]{2}{*}{ Dummy: Male } & $0.071^{* * *}$ & $0.075^{* * *}$ & $0.073^{* * *}$ & $0.069^{* * * *}$ & $0.080^{* * * *}$ & $0.078^{* * * *}$ \\
\hline & $(0.006)$ & $(0.010)$ & $(0.007)$ & $(0.006)$ & $(0.008)$ & $(0.012)$ \\
\hline \multirow[t]{2}{*}{ Dummy: Completed higher education } & $-0.025^{* *}$ & 0.021 & $-0.026^{*}$ & $-0.041^{* * *}$ & -0.023 & 0.011 \\
\hline & $(0.012)$ & $(0.020)$ & $(0.014)$ & $(0.013)$ & $(0.017)$ & $(0.025)$ \\
\hline \multirow[t]{2}{*}{ Dummy: Completed secondary education } & $-0.010^{*}$ & 0.006 & $-0.016^{* *}$ & $-0.016^{* * *}$ & -0.008 & 0.003 \\
\hline & $(0.006)$ & $(0.010)$ & $(0.007)$ & $(0.006)$ & $(0.008)$ & $(0.012)$ \\
\hline \multirow[t]{2}{*}{ Age } & $0.016^{* * *}$ & $0.017^{* * *}$ & $0.015^{* * *}$ & $0.014^{* * *}$ & $0.019^{* * *}$ & $0.022^{* * *}$ \\
\hline & $(0.001)$ & $(0.002)$ & $(0.001)$ & $(0.001)$ & $(0.002)$ & $(0.002)$ \\
\hline \multirow[t]{2}{*}{ Age squared } & $-0.014^{* * *}$ & $-0.015^{* * *}$ & $-0.013^{* * *}$ & $-0.012^{* * *}$ & $-0.016^{* * *}$ & $-0.019^{* * *}$ \\
\hline & $(0.001)$ & $(0.002)$ & $(0.001)$ & $(0.001)$ & $(0.002)$ & $(0.002)$ \\
\hline \multirow[t]{2}{*}{ Wage (predicted) } & -0.000 & -0.022 & 0.013 & 0.017 & -0.009 & $-0.040^{*}$ \\
\hline & $(0.012)$ & $(0.019)$ & $(0.014)$ & $(0.012)$ & $(0.017)$ & $(0.024)$ \\
\hline \multirow{2}{*}{$\begin{array}{l}\text { Dummy: Daily propensity of smoking } \\
\text { (predicted) }\end{array}$} & $-0.150^{* * * *}$ & $-0.128^{* * *}$ & $-0.134^{* * * *}$ & $-0.150^{* * * *}$ & $-0.191^{* * *}$ & $-0.185^{* * *}$ \\
\hline & $(0.020)$ & $(0.033)$ & $(0.025)$ & $(0.021)$ & $(0.028)$ & $(0.042)$ \\
\hline \multirow[t]{2}{*}{ Daily physical activity } & $0.007^{* * *}$ & 0.005 & $0.009^{* * *}$ & $0.010^{* * *}$ & 0.004 & 0.002 \\
\hline & $(0.002)$ & $(0.003)$ & $(0.002)$ & $(0.002)$ & $(0.003)$ & $(0.004)$ \\
\hline \multirow[t]{2}{*}{ Dummy: Urban area } & 0.004 & $-0.016^{* * *}$ & $-0.010^{* *}$ & 0.002 & $0.013^{* * *}$ & $0.019^{* * *}$ \\
\hline & $(0.003)$ & $(0.005)$ & $(0.004)$ & $(0.003)$ & $(0.004)$ & $(0.006)$ \\
\hline \multirow[t]{2}{*}{ Dummy: Capital city } & 0.000 & $0.015^{* * *}$ & $0.009^{* *}$ & -0.001 & $-0.010^{* *}$ & $-0.016^{* *}$ \\
\hline & $(0.003)$ & $(0.006)$ & $(0.004)$ & $(0.003)$ & $(0.004)$ & $(0.007)$ \\
\hline \multirow[t]{2}{*}{ Constant } & $2.885^{* * *}$ & $2.529^{* * *}$ & $2.572^{* * * *}$ & $2.803^{* * *}$ & $3.108^{* * * *}$ & $3.412^{* * *}$ \\
\hline & $(0.065)$ & $(0.115)$ & $(0.081)$ & $(0.068)$ & $(0.094)$ & $(0.142)$ \\
\hline (Pseudo) $\mathrm{R}^{2}$ & 0.242 & 0.139 & 0.140 & 0.153 & 0.130 & 0.125 \\
\hline $\mathrm{N}$ & 8,719 & 8,719 & 8,719 & 8,719 & 8,719 & 8,719 \\
\hline
\end{tabular}

Note: The dependent variable is $\log (\mathrm{BMI})$. Outliers $(1 \%)$ in the BMI were trimmed. Robust standard errors are presented in parentheses. Primary education is the reference category for the education dummy set. ${ }^{*} p<0.10,{ }^{* *} p<$ $0.05,{ }^{* * *} p<0.01$. 
Table 4: OLS and QR estimates of the second stage BMI equation (EI)

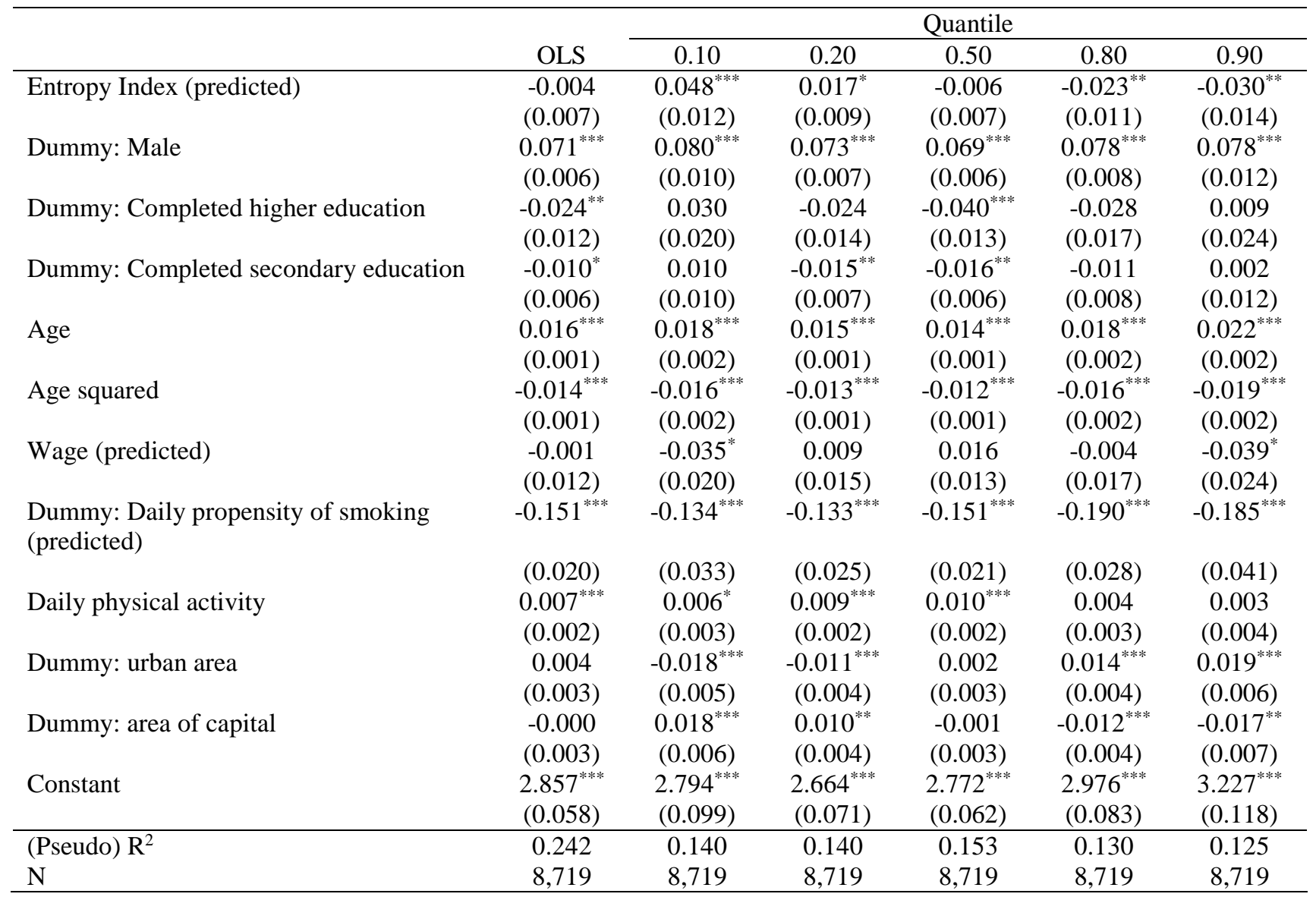

Note: The dependent variable is $\log (\mathrm{BMI})$. Outliers $(1 \%)$ in the BMI were trimmed. Robust standard errors are presented in parentheses. Primary education is the reference category for the education dummy set. ${ }^{*} p<0.10,{ }^{* *} p<$ $0.05,{ }^{* * *} p<0.01$. 
Table 5: OLS and QR estimates of the second stage BMI equation (DDS)

\begin{tabular}{|c|c|c|c|c|c|c|}
\hline \multirow[b]{2}{*}{ Variable } & \multirow[b]{2}{*}{ OLS } & \multicolumn{5}{|c|}{ Quantile } \\
\hline & & $\mathrm{Q}=0.1$ & $\mathrm{Q}=0.2$ & $\mathrm{Q}=0.5$ & $\mathrm{Q}=0.8$ & $\mathrm{Q}=0.9$ \\
\hline \multirow[t]{2}{*}{ Dietary Diversity Score (predicted) } & -0.002 & $0.009^{* * *}$ & $0.004^{*}$ & -0.002 & $-0.004^{*}$ & $-0.007^{* * *}$ \\
\hline & $(0.002)$ & $(0.003)$ & $(0.002)$ & $(0.002)$ & $(0.002)$ & $(0.003)$ \\
\hline \multirow[t]{2}{*}{ Dummy: Male } & $0.070^{* * * *}$ & $0.078^{* * * *}$ & $0.073^{* * *}$ & $0.068^{* * * *}$ & $0.076^{* * *}$ & $0.078^{* * * *}$ \\
\hline & $(0.006)$ & $(0.010)$ & $(0.007)$ & $(0.007)$ & $(0.008)$ & $(0.012)$ \\
\hline \multirow[t]{2}{*}{ Dummy: Completed higher education } & $-0.027^{* *}$ & 0.032 & -0.022 & $-0.043^{* * *}$ & -0.028 & -0.004 \\
\hline & $(0.012)$ & $(0.021)$ & $(0.015)$ & $(0.013)$ & $(0.018)$ & $(0.024)$ \\
\hline \multirow[t]{2}{*}{ Dummy: Completed secondary education } & $-0.011^{*}$ & 0.011 & $-0.013^{*}$ & $-0.017^{* * *}$ & -0.011 & -0.004 \\
\hline & $(0.006)$ & $(0.010)$ & $(0.008)$ & $(0.006)$ & $(0.009)$ & $(0.012)$ \\
\hline \multirow[t]{2}{*}{ Age } & $0.016^{* * *}$ & $0.018^{* * *}$ & $0.015^{* * *}$ & $0.014^{* * *}$ & $0.018^{* * *}$ & $0.021^{* * *}$ \\
\hline & $(0.001)$ & $(0.002)$ & $(0.001)$ & $(0.001)$ & $(0.002)$ & $(0.002)$ \\
\hline \multirow[t]{2}{*}{ Age squared } & $-0.014^{* * *}$ & $-0.016^{* * *}$ & $-0.013^{* * *}$ & $-0.012^{* * * *}$ & $-0.015^{* * *}$ & $-0.018^{* * *}$ \\
\hline & $(0.001)$ & $(0.002)$ & $(0.002)$ & $(0.001)$ & $(0.002)$ & $(0.002)$ \\
\hline \multirow[t]{2}{*}{ Wage (predicted) } & 0.003 & $-0.036^{*}$ & 0.008 & 0.018 & -0.004 & -0.026 \\
\hline & $(0.013)$ & $(0.020)$ & $(0.016)$ & $(0.013)$ & $(0.018)$ & $(0.024)$ \\
\hline \multirow{2}{*}{$\begin{array}{l}\text { Dummy: Daily propensity of smoking } \\
\text { (predicted) }\end{array}$} & $-0.148^{* * *}$ & $-0.129^{* * *}$ & $-0.133^{* * *}$ & $-0.150^{* * *}$ & $-0.185^{* * *}$ & $-0.187^{* * * *}$ \\
\hline & $(0.020)$ & $(0.033)$ & $(0.025)$ & $(0.021)$ & $(0.029)$ & $(0.042)$ \\
\hline \multirow[t]{2}{*}{ Daily physical activity } & $0.006^{* * *}$ & $0.005^{*}$ & $0.009^{* * *}$ & $0.010^{* * * *}$ & 0.004 & 0.003 \\
\hline & $(0.002)$ & $(0.003)$ & $(0.002)$ & $(0.002)$ & $(0.003)$ & $(0.004)$ \\
\hline \multirow[t]{2}{*}{ Dummy: urban area } & 0.006 & $-0.021^{* * *}$ & $-0.012^{* *}$ & 0.003 & $0.016^{* * *}$ & $0.022^{* * *}$ \\
\hline & $(0.004)$ & $(0.006)$ & $(0.005)$ & $(0.004)$ & $(0.005)$ & $(0.008)$ \\
\hline \multirow[t]{2}{*}{ Dummy: area of capital } & -0.000 & $0.020^{* * *}$ & $0.011^{* * *}$ & -0.001 & $-0.013^{* * *}$ & $-0.019^{* * *}$ \\
\hline & $(0.003)$ & $(0.006)$ & $(0.004)$ & $(0.003)$ & $(0.004)$ & $(0.007)$ \\
\hline \multirow[t]{2}{*}{ Constant } & $2.835^{* * *}$ & $2.882^{* * *}$ & $2.698^{* * *}$ & $2.754^{* * * *}$ & $2.938^{* * *}$ & $3.111^{* * *}$ \\
\hline & $(0.063)$ & $(0.103)$ & $(0.077)$ & $(0.068)$ & $(0.091)$ & $(0.121)$ \\
\hline (Pseudo) $\mathrm{R}^{2}$ & 0.243 & 0.139 & 0.140 & 0.153 & 0.130 & 0.125 \\
\hline $\mathrm{N}$ & 8,725 & 8,725 & 8,725 & 8,725 & 8,725 & 8,725 \\
\hline
\end{tabular}

Note: The dependent variable is $\log (\mathrm{BMI})$. Outliers $(1 \%)$ in the BMI were trimmed. Robust standard errors are presented in parentheses. Primary education is the reference category for the education dummy set. ${ }^{*} p<0.10,{ }^{* *} p<$ $0.05,{ }^{* * *} p<0.01$. 


\section{Appendix}

Table A.1 Descriptive statistics for the first stage diet diversity regressions

\begin{tabular}{|c|c|c|c|c|c|}
\hline Variable & $\mathbf{N}$ & Mean & SD & Min & Max \\
\hline Count Measure & 8,916 & 28.76 & 11.31 & 0.00 & 66.00 \\
\hline Simpson Index & 8,910 & 0.91 & 0.07 & 0.00 & 0.98 \\
\hline Entropy Index & 8,910 & 2.86 & 0.48 & 0.00 & 3.94 \\
\hline Dietary Diversity Score & 8,916 & 6.43 & 2.11 & 0.00 & 10.00 \\
\hline Household income (in euro/month) & 8,916 & 5521.52 & 4335.16 & 10.00 & 57700.00 \\
\hline $\begin{array}{l}\text { Consumption of own food production to household } \\
\text { income ratio }\end{array}$ & 8,739 & 0.02 & 0.05 & 0.00 & 0.94 \\
\hline $\begin{array}{l}\text { Food away from home (FAFH) consumption to } \\
\text { household income ratio }\end{array}$ & 8,739 & 0.01 & 0.04 & 0.00 & 1.00 \\
\hline Dummy: 1 st quarter & 8,916 & 0.25 & 0.43 & 0.00 & 1.00 \\
\hline Dummy: 2nd quarter & 8,916 & 0.26 & 0.44 & 0.00 & 1.00 \\
\hline Dummy: 3rd quarter & 8,916 & 0.25 & 0.43 & 0.00 & 1.00 \\
\hline Dummy: 4th quarter & 8,916 & 0.25 & 0.43 & 0.00 & 1.00 \\
\hline Dummy: Gjakova region & 8,916 & 0.14 & 0.34 & 0.00 & 1.00 \\
\hline Dummy: Gjilani region & 8,916 & 0.13 & 0.34 & 0.00 & 1.00 \\
\hline Dummy: Mitrovica region & 8,916 & 0.13 & 0.34 & 0.00 & 1.00 \\
\hline Dummy: Peja region & 8,916 & 0.14 & 0.35 & 0.00 & 1.00 \\
\hline Dummy: Prizren region & 8,916 & 0.16 & 0.36 & 0.00 & 1.00 \\
\hline Dummy: Prishtina region & 8,916 & 0.17 & 0.37 & 0.00 & 1.00 \\
\hline Dummy: Ferizaj region & 8,916 & 0.14 & 0.34 & 0.00 & 1.00 \\
\hline Dummy: Male & 8,916 & 0.50 & 0.50 & 0.00 & 1.00 \\
\hline Dummy: Higher education & 8,916 & 0.09 & 0.29 & 0.00 & 1.00 \\
\hline Dummy: Completed secondary education & 8,916 & 0.44 & 0.50 & 0.00 & 1.00 \\
\hline Dummy: Completed primary education & 8,916 & 0.46 & 0.50 & 0.00 & 1.00 \\
\hline Age & 8,916 & 41.05 & 17.06 & 18.00 & 103.00 \\
\hline Dummy: Employed & 8,916 & 0.89 & 0.31 & 0.00 & 1.00 \\
\hline Household size & 8,916 & 6.67 & 3.44 & 1.00 & 29.00 \\
\hline Dummy: Have children (aged below 7) & 8,916 & 0.42 & 0.49 & 0.00 & 1.00 \\
\hline Dummy: Urban area & 8,916 & 0.50 & 0.50 & 0.00 & 1.00 \\
\hline
\end{tabular}


Table A.2 Descriptive statistics for the first stage Heckman selection model for wages

\begin{tabular}{|c|c|c|c|c|c|}
\hline Variable & $\mathrm{N}$ & Mean & SD & Min & Max \\
\hline Wage (in euro/hour) & 2,018 & 7.97 & 0.65 & 3.93 & 10.59 \\
\hline Dummy: Male & 8,916 & 0.50 & 0.50 & 0.00 & 1.00 \\
\hline Dummy: Completed higher education & 8,916 & 0.09 & 0.29 & 0.00 & 1.00 \\
\hline Dummy: Completed secondary education & 8,916 & 0.44 & 0.50 & 0.00 & 1.00 \\
\hline Dummy: Completed primary education & 8,916 & 0.46 & 0.50 & 0.00 & 1.00 \\
\hline Age & 8,916 & 41.05 & 17.06 & 18.00 & 103.00 \\
\hline Dummy: 1st quarter & 8,916 & 0.25 & 0.43 & 0.00 & 1.00 \\
\hline Dummy: 2nd quarter & 8,916 & 0.26 & 0.44 & 0.00 & 1.00 \\
\hline Dummy: 3rd quarter & 8,916 & 0.25 & 0.43 & 0.00 & 1.00 \\
\hline Dummy: 4th quarter & 8,916 & 0.25 & 0.43 & 0.00 & 1.00 \\
\hline Dummy: Gjakova region & 8,916 & 0.14 & 0.34 & 0.00 & 1.00 \\
\hline Dummy: Gjilani region & 8,916 & 0.13 & 0.34 & 0.00 & 1.00 \\
\hline Dummy: Mitrovica region & 8,916 & 0.13 & 0.34 & 0.00 & 1.00 \\
\hline Dummy: Peja region & 8,916 & 0.14 & 0.35 & 0.00 & 1.00 \\
\hline Dummy: Prizren region & 8,916 & 0.16 & 0.36 & 0.00 & 1.00 \\
\hline Dummy: Prishtina region & 8,916 & 0.17 & 0.37 & 0.00 & 1.00 \\
\hline Dummy: Ferizaj region & 8,916 & 0.14 & 0.34 & 0.00 & 1.00 \\
\hline Dummy: Urban area & 8,916 & 0.50 & 0.50 & 0.00 & 1.00 \\
\hline Dummy: Rent, dividends, interest & 8,916 & 0.01 & 0.09 & 0.00 & 1.00 \\
\hline Dummy: Social welfare benefits & 8,916 & 0.02 & 0.14 & 0.00 & 1.00 \\
\hline Dummy: Pensions from Kosovo & 8,916 & 0.11 & 0.32 & 0.00 & 1.00 \\
\hline Dummy: Pensions from outside of Kosovo & 8,916 & 0.01 & 0.12 & 0.00 & 1.00 \\
\hline Dummy: Cash remittances from Kosovo & 8,916 & 0.00 & 0.06 & 0.00 & 1.00 \\
\hline Dummy: Cash sent from abroad by current HH members & 8,916 & 0.01 & 0.08 & 0.00 & 1.00 \\
\hline Dummy: Cash sent from abroad by relatives and other persons & 8,916 & 0.04 & 0.20 & 0.00 & 1.00 \\
\hline Dummy: Gifts in kind from abroad & 8,916 & 0.00 & 0.04 & 0.00 & 1.00 \\
\hline Household size & 8,916 & 6.67 & 3.44 & 1.00 & 29.00 \\
\hline Dummy: Have children (aged below 7) & 8,916 & 0.42 & 0.49 & 0.00 & 1.00 \\
\hline
\end{tabular}


Table A.3 Descriptive statistics for the first stage Probit model for smoking

\begin{tabular}{lccccc}
\hline Variable & $\mathrm{N}$ & Mean & SD & Min & Max \\
\hline Dummy: Smoker & 8,916 & 0.20 & 0.40 & 0.00 & 1.00 \\
Individual income (in euro/month) & 8,916 & 1293.54 & 2240.57 & 0.00 & 57700.00 \\
Dummy: Male & 8,916 & 0.50 & 0.50 & 0.00 & 1.00 \\
Dummy: Employed & 8,916 & 0.89 & 0.31 & 0.00 & 1.00 \\
Dummy: Completed higher education & 8,916 & 0.09 & 0.29 & 0.00 & 1.00 \\
Dummy: Completed secondary education & 8,916 & 0.44 & 0.50 & 0.00 & 1.00 \\
Dummy: Completed primary education & 8,916 & 0.46 & 0.50 & 0.00 & 1.00 \\
Age & 8,916 & 41.05 & 17.06 & 18.00 & 103.00 \\
Daily physical activity & 8,916 & 2.22 & 0.72 & 1.00 & 4.00 \\
Dummy: 1st quarter & 8,916 & 0.25 & 0.43 & 0.00 & 1.00 \\
Dummy: 2nd quarter & 8,916 & 0.26 & 0.44 & 0.00 & 1.00 \\
Dummy: 3rd quarter & 8,916 & 0.25 & 0.43 & 0.00 & 1.00 \\
Dummy: 4th quarter & 8,916 & 0.25 & 0.43 & 0.00 & 1.00 \\
Dummy: Gjakova region & 8,916 & 0.14 & 0.34 & 0.00 & 1.00 \\
Dummy: Gjilani region & 8,916 & 0.13 & 0.34 & 0.00 & 1.00 \\
Dummy: Mitrovica region & 8,916 & 0.13 & 0.34 & 0.00 & 1.00 \\
Dummy: Peja region & 8,916 & 0.14 & 0.35 & 0.00 & 1.00 \\
Dummy: Prizren region & 8,916 & 0.16 & 0.36 & 0.00 & 1.00 \\
Dummy: Prishtina region & 8,916 & 0.17 & 0.37 & 0.00 & 1.00 \\
Dummy: Ferizaj region & 8,916 & 0.14 & 0.34 & 0.00 & 1.00 \\
Dummy: Urban area & 8,916 & 0.50 & 0.50 & 0.00 & 1.00 \\
\hline
\end{tabular}


Table A.4 Correlation matrix of the diet diversity measures

\begin{tabular}{l|llll}
\hline & CM & SI & EI & DDS \\
\hline Count Measure (CM) & 1 & & & \\
Simpson Index (SI) & 0.60 & 1 & & \\
Entropy Index (EI) & 0.89 & 0.86 & 1 & \\
Dietary Diversity Score (DDS) & 0.87 & 0.61 & 0.83 & 1 \\
\hline
\end{tabular}


Table A.5 OLS estimates of food diversity demand equations

\begin{tabular}{|c|c|c|c|c|}
\hline Variable & $\mathrm{CM}$ & SI & EI & DDS \\
\hline \multirow[t]{2}{*}{ Household income $(\log )$} & $4.442^{* * *}$ & $0.015^{* * *}$ & $0.161^{* * *}$ & $0.659^{* * *}$ \\
\hline & $(0.329)$ & $(0.002)$ & $(0.015)$ & $(0.059)$ \\
\hline \multirow{2}{*}{$\begin{array}{l}\text { Consumption of own food production to } \\
\text { household income ratio }\end{array}$} & -6.841 & -0.039 & -0.321 & $-4.738^{* * *}$ \\
\hline & $(4.199)$ & $(0.061)$ & $(0.259)$ & $(1.307)$ \\
\hline \multirow[t]{2}{*}{ FAFH consumption to household income ratio } & -5.635 & -0.030 & -0.223 & $-1.521^{*}$ \\
\hline & $(3.988)$ & $(0.039)$ & $(0.241)$ & $(0.804)$ \\
\hline \multirow[t]{2}{*}{ Dummy: 1st quarter } & -0.886 & $-0.008^{*}$ & $-0.061^{* *}$ & $-0.224^{* *}$ \\
\hline & $(0.587)$ & $(0.004)$ & $(0.026)$ & $(0.095)$ \\
\hline \multirow[t]{2}{*}{ Dummy: 2nd quarter } & 0.062 & 0.001 & 0.004 & -0.109 \\
\hline & $(0.592)$ & $(0.004)$ & $(0.028)$ & $(0.096)$ \\
\hline \multirow[t]{2}{*}{ Dummy: 3rd quarter } & -0.114 & 0.004 & 0.008 & $-0.247^{* *}$ \\
\hline & $(0.601)$ & $(0.004)$ & $(0.026)$ & $(0.101)$ \\
\hline \multirow[t]{2}{*}{ Dummy: Male } & $-0.406^{* * *}$ & -0.001 & $-0.014^{* *}$ & $-0.105^{* * *}$ \\
\hline & $(0.145)$ & $(0.001)$ & $(0.007)$ & $(0.026)$ \\
\hline \multirow[t]{2}{*}{ Dummy: Completed higher education } & $2.047^{* * *}$ & $0.006^{* *}$ & $0.073^{* * *}$ & $0.357^{* * *}$ \\
\hline & $(0.520)$ & $(0.003)$ & $(0.021)$ & $(0.077)$ \\
\hline \multirow[t]{2}{*}{ Dummy: Completed secondary education } & $0.953^{* * *}$ & 0.003 & $0.038^{* * *}$ & $0.212^{* * *}$ \\
\hline & $(0.298)$ & $(0.002)$ & $(0.014)$ & $(0.053)$ \\
\hline \multirow[t]{2}{*}{ Age } & 0.044 & 0.000 & 0.002 & 0.001 \\
\hline & $(0.038)$ & $(0.000)$ & $(0.002)$ & $(0.007)$ \\
\hline \multirow[t]{2}{*}{ Age squared } & -0.054 & -0.000 & -0.003 & -0.001 \\
\hline & $(0.047)$ & $(0.000)$ & $(0.002)$ & $(0.008)$ \\
\hline \multirow[t]{2}{*}{ Dummy: Employed } & 0.138 & -0.006 & -0.014 & 0.050 \\
\hline & $(0.642)$ & $(0.004)$ & $(0.028)$ & $(0.114)$ \\
\hline \multirow[t]{2}{*}{ Household size } & -0.048 & $-0.002^{* *}$ & -0.009 & $-0.074^{* * * *}$ \\
\hline & $(0.117)$ & $(0.001)$ & $(0.006)$ & $(0.016)$ \\
\hline \multirow[t]{2}{*}{ Dummy: Have children (aged below 7) } & 0.815 & 0.005 & 0.036 & $0.143^{*}$ \\
\hline & $(0.500)$ & $(0.003)$ & $(0.023)$ & $(0.084)$ \\
\hline \multirow[t]{2}{*}{ Dummy: Urban area } & $6.489^{* * *}$ & $0.023^{* * *}$ & $0.240^{* * *}$ & $1.577^{* * *}$ \\
\hline & $(0.434)$ & $(0.003)$ & $(0.019)$ & $(0.078)$ \\
\hline \multirow[t]{2}{*}{ Constant } & $-14.774^{* * *}$ & $0.769^{* * *}$ & $1.313^{* * *}$ & 0.179 \\
\hline & $(2.793)$ & $(0.021)$ & $(0.129)$ & $(0.502)$ \\
\hline Regional controls & YES & YES & YES & YES \\
\hline $\mathrm{R}^{2}$ & 0.374 & 0.187 & 0.317 & 0.469 \\
\hline $\mathrm{N}$ & 8,739 & 8,733 & 8,733 & 8,739 \\
\hline
\end{tabular}

Note: Standard errors clustered at household level are presented in parentheses. Dummy variables for primary education, $4^{\text {th }}$ quarter, and region of Ferizaj are the reference categories for the respective dummy sets. ${ }^{*} p<0.10,{ }^{* *} p<$ $0.05,{ }^{* * *} p<0.01$. 
Table A.6 Estimates of Probit model for propensity of smoking

\begin{tabular}{lc}
\hline Variable & $0.046^{* * *}$ \\
\hline Individual income (log) & $(0.005)$ \\
Dummy: Male & $0.805^{* * *}$ \\
& $(0.041)$ \\
Dummy: Employed & 0.117 \\
& $(0.102)$ \\
Dummy: Completed higher education & $-0.357^{* * *}$ \\
Dummy: Completed secondary education & $(0.065)$ \\
& -0.009 \\
Age & $(0.040)$ \\
Age squared & $0.094^{* * *}$ \\
Daily physical activity & $(0.008)$ \\
Dummy: 1st quarter & $-0.095^{* * *}$ \\
Dummy: 2nd quarter & $(0.009)$ \\
Dummy: 3rd quarter & -0.025 \\
Dummy: Urban area & $(0.025)$ \\
Constant & 0.002 \\
Regional controls & $(0.047)$ \\
\hline Pseudo R & $0.093^{* *}$ \\
\hline Note: Robust standard & $(0.046)$ \\
& -0.019 \\
& $(0.047)$ \\
& $0.118^{* * *}$ \\
& $(0.034)$ \\
& $-3.496^{* * *}$ \\
& $(0.147)$ \\
\hline
\end{tabular}

Note: Robust standard errors are presented in parentheses. Dummy variables for primary education, $4^{\text {th }}$ quarter, and the region of Ferizaj are the reference categories for the respective dummy sets. ${ }^{*} p<0.10,{ }^{* *} p<0.05,{ }^{* * *} p<0.01$. 
Table A.7 Estimates of Heckman selection model for wages

\begin{tabular}{|c|c|c|}
\hline Variable & $\begin{array}{l}\text { Selection } \\
\text { equation }\end{array}$ & $\begin{array}{l}\text { Levels } \\
\text { equation }\end{array}$ \\
\hline Dummy: Rent, dividends, interest & $\begin{array}{c}-0.853^{* * * *} \\
(0.193)\end{array}$ & \\
\hline Dummy: Social welfare benefits & $\begin{array}{c}-0.720^{* * * *} \\
(0.131)\end{array}$ & \\
\hline Dummy: Pensions from Kosovo & $\begin{array}{c}-1.843^{* * *} \\
(0.234)\end{array}$ & \\
\hline Dummy: Pensions from outside of Kosovo & $\begin{array}{c}-1.289^{* * * *} \\
(0.350)\end{array}$ & \\
\hline Dummy: Cash remittances from Kosovo & $\begin{array}{c}-1.040^{* * *} \\
(0.415)\end{array}$ & \\
\hline Dummy: Cash sent from abroad by current $\mathrm{HH}$ members & $\begin{array}{c}-0.695^{* * * *} \\
(0.238)\end{array}$ & \\
\hline Dummy: Cash sent from abroad by relatives and other persons & $\begin{array}{c}-0.924^{* * *} \\
(0.109)\end{array}$ & \\
\hline Dummy: Gifts in kind from abroad & $\begin{array}{c}-0.746 \\
(0.627)\end{array}$ & \\
\hline Household size & $\begin{array}{c}-0.035^{* * * *} \\
(0.006)\end{array}$ & \\
\hline Dummy: Have children (aged below 7) & $\begin{array}{c}-0.168^{* * * *} \\
(0.040)\end{array}$ & \\
\hline Dummy: Male & $\begin{array}{c}1.118^{* * *} \\
(0.038)\end{array}$ & $\begin{array}{l}0.180^{* *} \\
(0.072)\end{array}$ \\
\hline Dummy: Completed higher education & $\begin{array}{c}1.112^{* * *} \\
(0.059)\end{array}$ & $\begin{array}{c}0.992^{\text {**** }} \\
(0.075)\end{array}$ \\
\hline Dummy: Completed secondary education & $\begin{array}{c}0.378^{* * *} \\
(0.041)\end{array}$ & $\begin{array}{c}0.448^{* * * *} \\
(0.042)\end{array}$ \\
\hline Age & $\begin{array}{c}0.142^{* * * *} \\
(0.009)\end{array}$ & $\begin{array}{c}0.073^{\text {**** }} \\
(0.012)\end{array}$ \\
\hline Age squared & $\begin{array}{c}-0.158^{* * *} \\
(0.011)\end{array}$ & $\begin{array}{c}-0.077^{* * * *} \\
(0.014)\end{array}$ \\
\hline Dummy: 1st quarter & $\begin{array}{c}-0.165^{* * * *} \\
(0.050)\end{array}$ & $\begin{array}{c}-0.177^{* * * *} \\
(0.039)\end{array}$ \\
\hline Dummy: 2nd quarter & $\begin{array}{c}0.018 \\
(0.049)\end{array}$ & $\begin{array}{c}-0.076^{* * *} \\
(0.037)\end{array}$ \\
\hline Dummy: 3rd quarter & $\begin{array}{c}-0.038 \\
(0.049)\end{array}$ & $\begin{array}{c}-0.075^{* *} \\
(0.037)\end{array}$ \\
\hline Dummy: Urban area & $\begin{array}{c}0.200^{* * *} \\
(0.036)\end{array}$ & $\begin{array}{l}0.061^{* *} \\
(0.030)\end{array}$ \\
\hline Constant & $\begin{array}{c}-4.239^{* * *} \\
(0.184) \\
\end{array}$ & $\begin{array}{l}5.409^{* * *} \\
(0.381)\end{array}$ \\
\hline Regional controls & YES & YES \\
\hline Inverse Mills ratio (lambda) & $\begin{array}{c}0.306^{* * *} \\
(0.087)\end{array}$ & \\
\hline Rho & 0.500 & \\
\hline Sigma & 0.625 & \\
\hline Number of individuals & 8,916 & \\
\hline Number censored observations & 6,898 & \\
\hline
\end{tabular}

Note: Robust standard errors are presented in parentheses. Dummy variables for primary education, $4^{\text {th }}$ quarter, and region of Ferizaj are the reference categories for the respective dummy sets. ${ }^{*} p<0.10,{ }^{* *} p<0.05,{ }^{* * *} p<0.01$. 
Table A.8 OLS estimates of BMIs' determinants (by gender)

\begin{tabular}{|c|c|c|c|c|c|c|c|c|}
\hline \multirow[b]{2}{*}{ Variable } & \multicolumn{8}{|c|}{ Gender } \\
\hline & Male & Female & Male & Female & Male & Female & Male & Female \\
\hline Count Measure (predicted) & $\begin{array}{c}0.000 \\
(0.000)\end{array}$ & $\begin{array}{l}-0.000 \\
(0.000)\end{array}$ & & & & & & \\
\hline Simpson Index (predicted) & & & $\begin{array}{l}-0.095 \\
(0.090)\end{array}$ & $\begin{array}{c}-0.040 \\
(0.087)\end{array}$ & & & & \\
\hline Entropy Index (predicted) & & & & & $\begin{array}{c}-0.007 \\
(0.010)\end{array}$ & $\begin{array}{c}-0.005 \\
(0.010)\end{array}$ & & \\
\hline Dietary Diversity Score (predicted) & & & & & & & $\begin{array}{l}-0.001 \\
(0.002)\end{array}$ & $\begin{array}{c}-0.003 \\
(0.002)\end{array}$ \\
\hline Dummy: Completed higher education & $\begin{array}{c}0.001 \\
(0.017)\end{array}$ & $\begin{array}{c}-0.041^{* *} \\
(0.017)\end{array}$ & $\begin{array}{l}-0.005 \\
(0.017)\end{array}$ & $\begin{array}{c}-0.038^{* *} \\
(0.017)\end{array}$ & $\begin{array}{l}-0.003 \\
(0.017)\end{array}$ & $\begin{array}{c}-0.039^{* *} \\
(0.017)\end{array}$ & $\begin{array}{l}-0.003 \\
(0.018)\end{array}$ & $\begin{array}{c}-0.046^{* * *} \\
(0.018)\end{array}$ \\
\hline Dummy: Completed secondary education & $\begin{array}{c}0.003 \\
(0.008)\end{array}$ & $\begin{array}{c}-0.019^{* *} \\
(0.008)\end{array}$ & $\begin{array}{l}-0.000 \\
(0.008)\end{array}$ & $\begin{array}{c}-0.018^{* *} \\
(0.008)\end{array}$ & $\begin{array}{c}0.001 \\
(0.008)\end{array}$ & $\begin{array}{c}-0.018^{* *} \\
(0.008)\end{array}$ & $\begin{array}{c}0.001 \\
(0.009)\end{array}$ & $\begin{array}{c}-0.022^{* *} \\
(0.009)\end{array}$ \\
\hline Age & $\begin{array}{c}0.014^{* * * *} \\
(0.002)\end{array}$ & $\begin{array}{c}0.017^{* * * *} \\
(0.002)\end{array}$ & $\begin{array}{c}0.013^{* * * *} \\
(0.002)\end{array}$ & $\begin{array}{c}0.017^{* * * *} \\
(0.002)\end{array}$ & $\begin{array}{c}0.013^{* * *} \\
(0.002)\end{array}$ & $\begin{array}{c}0.017^{* * * *} \\
(0.002)\end{array}$ & $\begin{array}{c}0.013^{* * *} \\
(0.002)\end{array}$ & $\begin{array}{c}0.016^{* * * *} \\
(0.002)\end{array}$ \\
\hline Age squared & $\begin{array}{c}-0.013^{* * * *} \\
(0.002)\end{array}$ & $\begin{array}{c}-0.014^{* * * *} \\
(0.002)\end{array}$ & $\begin{array}{c}-0.012^{* * * *} \\
(0.002)\end{array}$ & $\begin{array}{c}-0.014^{* * * *} \\
(0.002)\end{array}$ & $\begin{array}{c}-0.012^{* * * *} \\
(0.002)\end{array}$ & $\begin{array}{c}-0.014^{* * * *} \\
(0.002)\end{array}$ & $\begin{array}{c}-0.012^{* * * *} \\
(0.002)\end{array}$ & $\begin{array}{c}-0.013^{* * *} \\
(0.002)\end{array}$ \\
\hline Wage (predicted) & $\begin{array}{c}0.000 \\
(0.018)\end{array}$ & $\begin{array}{c}0.000 \\
(0.017)\end{array}$ & $\begin{array}{c}0.009 \\
(0.017)\end{array}$ & $\begin{array}{c}-0.004 \\
(0.016)\end{array}$ & $\begin{array}{c}0.006 \\
(0.017)\end{array}$ & $\begin{array}{c}-0.003 \\
(0.017)\end{array}$ & $\begin{array}{c}0.006 \\
(0.019)\end{array}$ & $\begin{array}{c}0.007 \\
(0.018)\end{array}$ \\
\hline Dummy: Daily propensity of smoking (predicted) & $\begin{array}{c}-0.085^{* * *} \\
(0.032)\end{array}$ & $\begin{array}{c}-0.202^{* * * *} \\
(0.066)\end{array}$ & $\begin{array}{c}-0.077^{* *} \\
(0.031)\end{array}$ & $\begin{array}{c}-0.208^{* * *} \\
(0.066)\end{array}$ & $\begin{array}{c}-0.079^{* *} \\
(0.031)\end{array}$ & $\begin{array}{c}-0.206^{* * * *} \\
(0.066)\end{array}$ & $\begin{array}{c}-0.080^{* * *} \\
(0.032)\end{array}$ & $\begin{array}{c}-0.194^{* * * *} \\
(0.066)\end{array}$ \\
\hline Daily physical activity & $\begin{array}{c}0.006^{* * * *} \\
(0.002)\end{array}$ & $\begin{array}{c}0.005 \\
(0.004)\end{array}$ & $\begin{array}{l}0.005^{* *} \\
(0.002)\end{array}$ & $\begin{array}{c}0.005 \\
(0.004)\end{array}$ & $\begin{array}{l}0.006^{* *} \\
(0.002)\end{array}$ & $\begin{array}{c}0.005 \\
(0.004)\end{array}$ & $\begin{array}{c}0.006^{* * *} \\
(0.002)\end{array}$ & $\begin{array}{c}0.005 \\
(0.004)\end{array}$ \\
\hline Dummy: Urban area & $\begin{array}{c}0.002 \\
(0.004)\end{array}$ & $\begin{array}{c}0.004 \\
(0.005)\end{array}$ & $\begin{array}{c}0.004 \\
(0.004)\end{array}$ & $\begin{array}{c}0.003 \\
(0.004)\end{array}$ & $\begin{array}{c}0.004 \\
(0.004)\end{array}$ & $\begin{array}{c}0.004 \\
(0.005)\end{array}$ & $\begin{array}{c}0.004 \\
(0.005)\end{array}$ & $\begin{array}{c}0.007 \\
(0.005)\end{array}$ \\
\hline Dummy: Capital city & $\begin{array}{c}-0.018^{* * * *} \\
(0.005)\end{array}$ & $\begin{array}{c}0.018^{* * * *} \\
(0.005)\end{array}$ & $\begin{array}{c}-0.018^{* * * *} \\
(0.004)\end{array}$ & $\begin{array}{c}0.018^{* * *} \\
(0.005)\end{array}$ & $\begin{array}{c}-0.018^{* * * *} \\
(0.004)\end{array}$ & $\begin{array}{c}0.018^{* * *} \\
(0.005)\end{array}$ & $\begin{array}{c}-0.018^{* * * *} \\
(0.005)\end{array}$ & $\begin{array}{c}0.018^{* * * *} \\
(0.005)\end{array}$ \\
\hline Constant & $\begin{array}{c}2.947^{* * * *} \\
(0.093) \\
\end{array}$ & $\begin{array}{c}2.835^{\text {**** }} \\
(0.087) \\
\end{array}$ & $\begin{array}{c}2.986^{* * * *} \\
(0.091)\end{array}$ & $\begin{array}{c}2.883^{* * * *} \\
(0.092) \\
\end{array}$ & $\begin{array}{c}2.934^{* * * *} \\
(0.084)\end{array}$ & $\begin{array}{c}2.857^{* * * *} \\
(0.081) \\
\end{array}$ & $\begin{array}{c}2.925^{* * * *} \\
(0.095)\end{array}$ & $\begin{array}{c}2.809^{* * * *} \\
(0.088) \\
\end{array}$ \\
\hline $\begin{array}{l}\mathrm{R}^{2} \\
\mathrm{~N}\end{array}$ & $\begin{array}{l}0.167 \\
4,313\end{array}$ & $\begin{array}{l}0.304 \\
4,412\end{array}$ & $\begin{array}{l}0.167 \\
4,310\end{array}$ & $\begin{array}{l}0.304 \\
4,409\end{array}$ & $\begin{array}{l}0.167 \\
4,310\end{array}$ & $\begin{array}{l}0.304 \\
4,409\end{array}$ & $\begin{array}{l}0.167 \\
4,313\end{array}$ & $\begin{array}{l}0.304 \\
4,412\end{array}$ \\
\hline
\end{tabular}

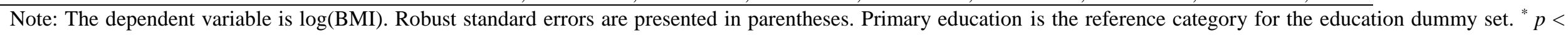
$0.10,{ }^{* *} p<0.05,{ }^{* * *} p<0.01$. 